\title{
COVID-19 AND NON-IRISH NATIONALS IN IRELAND
}

Shannen Enright, Frances McGinnity

Ivan Privalko, Helen Russell

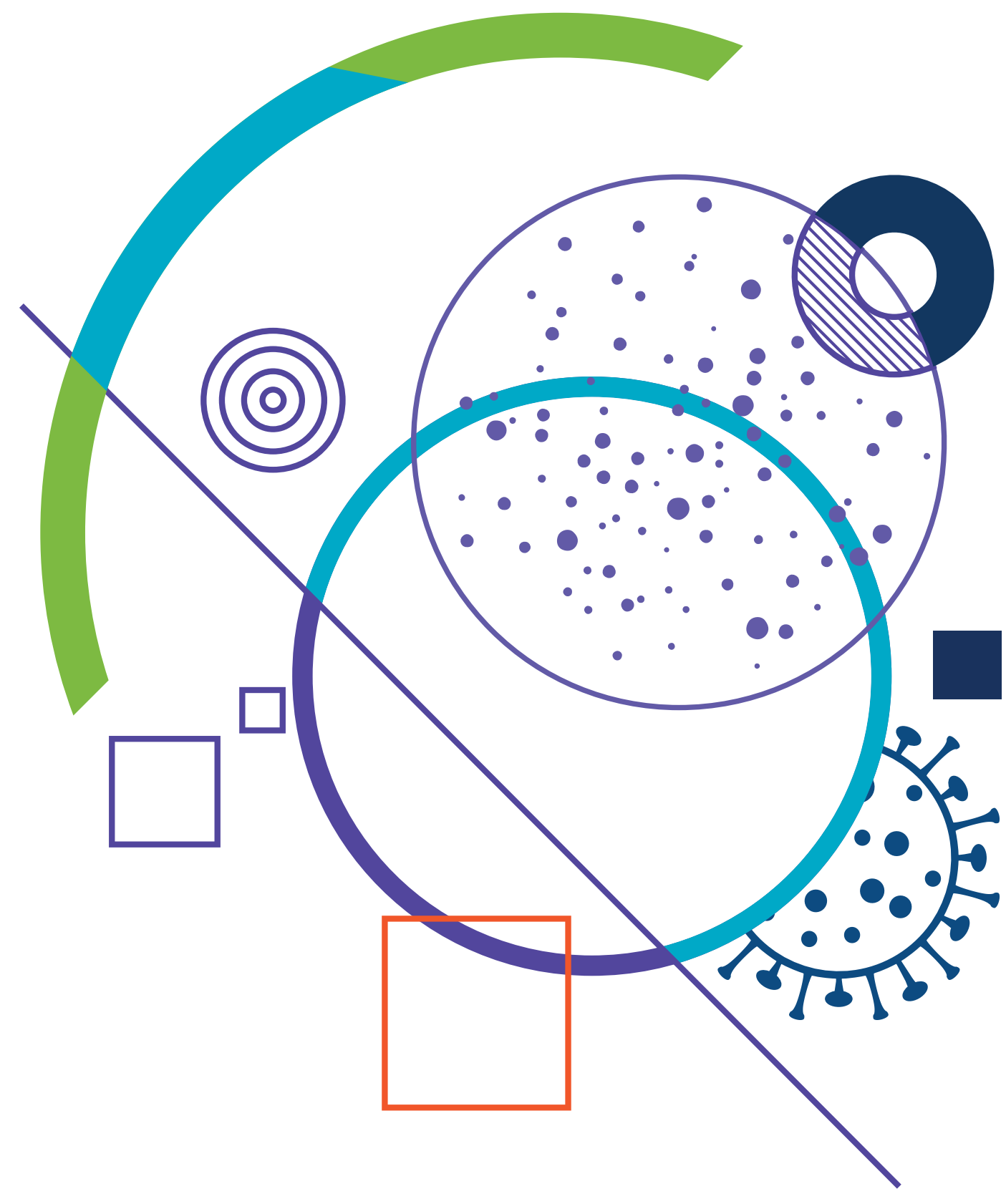


Funded by the Department of Children, Equality, Disability, Integration and Youth in line with the Migrant Integration Strategy 2017-2020 


\title{
COVID-19 AND NON-IRISH NATIONALS IN IRELAND
}

\author{
Shannen Enright \\ Frances McGinnity \\ Ivan Privalko \\ Helen Russell
}

December 2020

Economic and Social Research Institute

Department of Children, Equality, Disability, Integration and Youth

Available to download from www.esri.ie

(C) 2020 The Economic and Social Research Institute

Whitaker Square, Sir John Rogerson's Quay, Dublin 2

https://doi.org/10.26504/bkmnext404

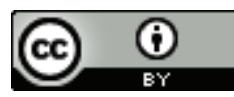

This Open Access work is licensed under a Creative Commons Attribution 4.0 International License (https://creativecommons.org/licenses/by/4.0/), which permits unrestricted use, distribution, and reproduction in any medium, provided the original work is properly credited. 


\section{ABOUT THE ESRI}

The mission of the Economic and Social Research Institute is to advance evidencebased policymaking that supports economic sustainability and social progress in Ireland. ESRI researchers apply the highest standards of academic excellence to challenges facing policymakers, focusing on 12 areas of critical importance to 21st Century Ireland.

The Institute was founded in 1960 by a group of senior civil servants led by Dr T.K. Whitaker, who identified the need for independent and in-depth research analysis to provide a robust evidence base for policymaking in Ireland.

Since then, the Institute has remained committed to independent research and its work is free of any expressed ideology or political position. The Institute publishes all research reaching the appropriate academic standard, irrespective of its findings or who funds the research.

The quality of its research output is guaranteed by a rigorous peer review process. ESRI researchers are experts in their fields and are committed to producing work that meets the highest academic standards and practices.

The work of the Institute is disseminated widely in books, journal articles and reports. ESRI publications are available to download, free of charge, from its website. Additionally, ESRI staff communicate research findings at regular conferences and seminars.

The ESRI is a company limited by guarantee, answerable to its members and governed by a Council, comprising 14 members who represent a cross-section of ESRI members from academia, civil services, state agencies, businesses and civil society. The Institute receives an annual grant-in-aid from the Department of Public Expenditure and Reform to support the scientific and public interest elements of the Institute's activities; the grant accounted for an average of 30 per cent of the Institute's income over the lifetime of the last Research Strategy. The remaining funding comes from research programmes supported by government departments and agencies, public bodies and competitive research programmes.

Further information is available at www.esri.ie 


\section{THE AUTHORS}

Shannen Enright is a research assistant at the Economic and Social Research Institute (ESRI). Frances McGinnity is an Associate Research Professor at the ESRI and Adjunct Professor at Trinity College Dublin (TCD). Ivan Privalko is a PostDoctoral Researcher at the ESRI. Helen Russell is a Research Professor at the ESRI and an Adjunct Professor at TCD.

\section{ACKNOWLEDGEMENTS}

This publication is the seventh report in a research programme on integration and equality at the ESRI, now funded by the Department of Children, Equality, Disability, Integration and Youth, in line with the Migrant Integration Strategy 2017-2020. We would like to express our thanks to the members of the steering group for comments on the study - Úna Ní Dhubhghaill (Department of Children, Equality, Disability, Integration and Youth), Edwina Steele (Department of Children, Equality, Disability, Integration and Youth), Professor Philip O'Connell (University College Dublin), Declan Costello (Department of Justice and Equality) and Emma Quinn (ESRI/EMN Ireland). We would also like to thank Anne Nolan, ESRI, for her insightful comments as editor of the report and to the internal ESRI reviewer who provided valuable comments.

Special thanks to statisticians from the CSO - Steven Conroy and Kieran Culhane who prepared the tables on COVID-19 deaths and cases by matching data from the Computerised Infectious Disease Reporting database with Census 2016 data, and Jim Dalton for his amiable and efficient assistance with the Labour Force Survey data. Thanks to our ESRI colleague Paul Redmond for sharing his programme to code the LFS data on keyworkers, which we then expanded to update to October 2020 level 5 restrictions. We wish to thank Anna de Courcy for copyediting the report and Sarah Burns for managing its publication.

This report has been accepted for publication by the Institute, which does not itself take institutional policy positions. The report has been peer reviewed prior to publication. The authors are solely responsible for the content and the views expressed. 



\section{TABLE OF CONTENTS}

EXECUTIVE SUMMARY

IX

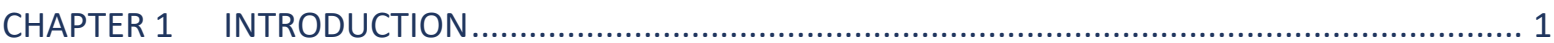

1.1 COVID and non-nationals in the labour market: international/Irish experience .......... 2

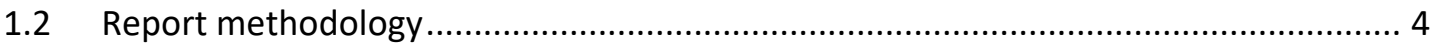

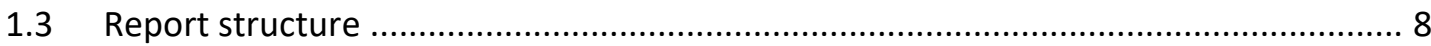

CHAPTER 2 VULNERABILITY OF CONTRACTING COVID-19 AMONG NON-IRISH NATIONALS

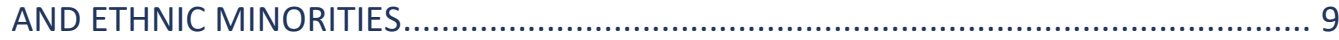

2.1 COVID-19 in Ireland: profile of deaths and cases by ethnicity and nationality ........... 10

2.2 COVID-19 in Ireland: higher risk living and working conditions ................................ 15

CHAPTER 3 EMPLOYMENT PRE-PANDEMIC, POLICY RESPONSES TO COVID AND MIGRATION TRENDS

3.1 Employment of non-Irish nationals prior to the pandemic 19

3.2 Policy response to COVID-19: implications for non-Irish nationals

CHAPTER 4 ARE NON-IRISH NATIONALS MORE VULNERABLE TO THE LABOUR MARKET

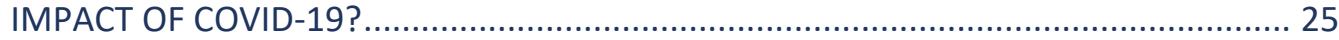

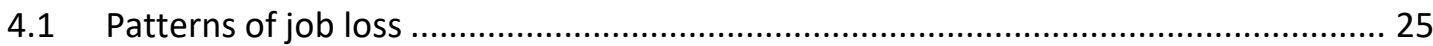

4.2 Measuring the impact of COVID-19 on employment ................................................. 27

4.3 Receipt of PUP and TWSS (pandemic related supports) ............................................. 28

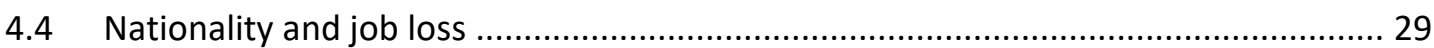

4.5 Nationality and COVID-related absence ….............................................................. 35

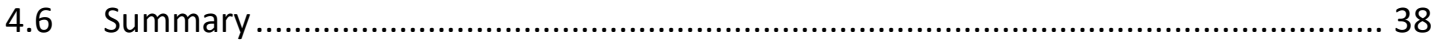

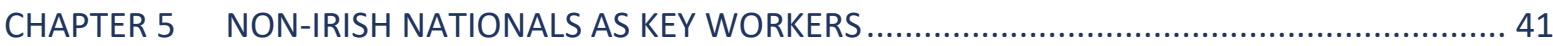

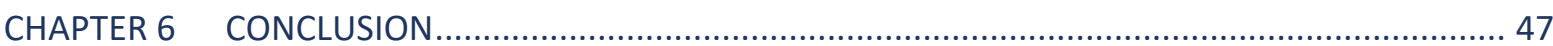

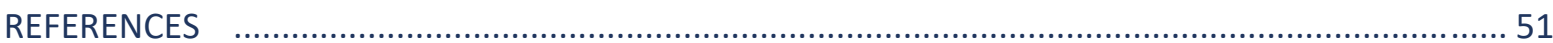

APPENDIX 



\section{LIST OF TABLES}

Table 2.1 Profile of COVID-19 cases by ethnicity and nationality in Ireland 12

Table 2.2 Profile of COVID-19 deaths by ethnicity and nationality in Ireland............................ 14

Table $3.1 \quad$ Irish and non-Irish nationals sector breakdown Q1 2018 and 2019 (LFS) .................. 21

Table 4.1 Proportion receiving PUP payments by nationality group ........................................... 28

Table 4.2 Proportion receiving TWSS payments by nationality group ...................................... 29

Table 4.3 Factors influencing employment LFS Q1 pre-pandemic and Q2 pandemic: odds

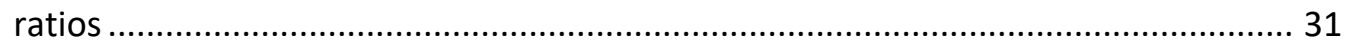

Table 4.4 Multinomial model of factors associated with COVID-related absence (Q2)............. 36

Table A1.1 Operational definitions and examples of key workers .............................................. 57

Table A4.1 Factors influencing employment in Q1 and Q2 2020 (odds ratios)........................... 59

Table A4.2 Factors influencing employment in Q1 and Q2 2020 for men and women (odds

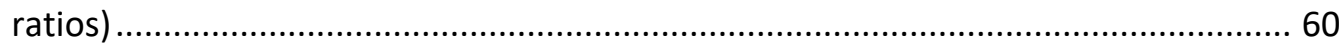

Table A4.3 Factors influencing employment in Q1 and Q2 2020 for younger and older workers (odds ratios)

Table A4.4 Factors associated with unemployment or inactivity due to non-COVID reasons (compared to employment) Q2 2020; relative risk ratios 62

Table A4.5 Factors associated with COVID absence, unemployment or inactivity due to nonCOVID reasons (compared to employment) with interactions 


\section{LIST OF FIGURES}

Figure 3.1 Irish and non-Irish nationals sector breakdown Q1 2018 and 2019......................... 20

Figure 4.1 Decline in employment by sector between Q1 and Q2 2020................................ 25

Figure 4.2 Occupational 'remotability' by nationality group, Q1 2020 ...................................... 27

Figure 4.3 Predicted probability of employment in Q1 and Q2 2020 by nationality .................. 32

Figure 4.4 Predicted probability of employment in Q1 and Q2 2020 by level of homeworking in occupation

Figure 4.5 Predicted probability of employment in Q1 and Q2 2020 by nationality for men and women

Figure 4.6 Predicted probability of employment in Q1 and Q2 2020 by nationality for younger (under 30 ) and older (30 and older) age groups

Figure 4.7 Predicted probability of COVID-related absence versus employment for men and women, Q2 2020......

Figure 4.8 Predicted probability of COVID-related absence versus employment for graduates and non-graduates by nationality......

Figure 5.1 Proportion of Irish and non-Irish nationals classified as key workers (LFS 2017-2019)

Figure 5.2 Proportion of Irish and non-Irish nationals classified as key workers in health and related sectors (LFS 2017-2019)

Figure 5.3 Proportion of Irish and non-Irish nationals classified as key workers in essential manufacturing (LFS 2017-2019).

Figure 5.4 Proportion of Irish and non-Irish nationals classified as key workers in education sector (LFS 2017-2019) 


\section{GLOSSARY}

CIDR Computerised Infectious Disease Reporting database

Cocooning Cocooning involves staying at home, reducing face to face interaction and restricting your movement to minimise your risk of getting COVID-19

CSO Central Statistics Office

Ethnicity Self-defined ethnic group based on Irish Census classification of ethnicity

EU-East Includes EU Member States which joined the European Union from 2004 onwards: Bulgaria, Croatia, Cyprus, Czech Republic, Estonia, Hungary, Latvia, Lithuania, Malta, Poland, Romania, Slovakia and Slovenia

EU-West 'Old' EU Member States, excluding Ireland and the UK: Austria, Belgium, Denmark, Finland, France, Germany, Greece, Italy, Luxembourg, Netherlands, Portugal, Spain and Sweden

EU-West* Includes same countries as EU-West with the addition of the United Kingdom

EWSS Employment Wage Subsidy Scheme. This replaced the Temporary Wage Subsidy Scheme on 1 September 2020

ILO International Labour Organization

LFS Labour Force Survey

Migrant Typically refers to someone born outside their country of residence. In Ireland, many of those born abroad are non-Irish nationals but a substantial minority are Irish citizens by naturalisation or descent

Nationality Respondents are asked if they are an Irish citizen. If they are not an Irish citizen, they are asked for their country of citizenship

Non-EU Includes all countries which are not EU Member States (excludes United Kingdom)

Occupation Occupation refers to the role a worker plays in the organisation. Jobs are classified in terms of their skill level and content using the International Standard Classification of Occupations (ISCO) codes

OECD Organisation for Economic Co-operation and Development

PUP Pandemic Unemployment Payment

Remotability The extent to which a job can be performed remotely

Sector Sector refers to the economic activity of the organisation someone works for, based on the European industrial activity classification (NACE Rev.2) classification scheme 



\section{EXECUTIVE SUMMARY}

\section{Summary of Findings}

- In this report we examine the impact of COVID-19 on the labour force outcomes of non-Irish nationals compared to their Irish peers using Labour Force Survey data. In addition, we examine the proportion of non-Irish nationals who are likely to be 'key workers' using Labour Force Survey data collected prior to the pandemic. We also briefly compare statistics on COVID-19 cases and deaths by nationality (whether or not someone is an Irish citizen) and ethnicity (their self-defined ethnic group).

- The report uses a number of different measures of the potential labour market impact of the pandemic: fall in employment between Q1 2020 and Q2 2020; those who record a COVID-related absence from work in Q2 2020, even though they have, at least in principle, a job to go back to; and receipt of COVID-related welfare payments (from administrative statistics).

- Results from our statistical models of employment show that overall, the odds ratio of being in employment for all workers were halved in Q2 2020 compared to Q1. The fall in employment was found to be much sharper for Eastern European nationals compared to Irish nationals. Non-EU nationals were found to have a significantly lower probability of employment in both quarters compared to Irish nationals but the scale of the decline in employment was similar for both non-EU and Irish nationals. Western European nationals (which includes UK nationals in these models) were not found to have been disproportionately affected by the decline in employment levels due to the pandemic.

- Those who work in occupations which are associated with medium or high levels of working from home have higher odds of being in employment. Results from our models show that there is a less severe drop in employment due to the pandemic for those working in occupations where they can work from home. Non-EU nationals and Western Europeans are more likely to be working in jobs associated with high levels of working from home: Eastern European nationals are much less likely to be working in these jobs than Irish nationals.

- $\quad$ The fall in employment between Q1 and Q2 for both women and men is similar for Irish, EU-West and non-EU nationals, with women more likely to experience job loss in all three groups. However, looking at EU-East we find the drop in employment was particularly sharp for women who are Eastern European nationals. We also find that the drop in employment is sharper among Eastern European nationals compared to Irish nationals. 
The report also examines COVID-related absence from work, defined as a temporary absence due to COVID (e.g. business closures due to public health measures), from a job or business which an individual expects to go back to. Controlling for age and gender, Eastern European nationals have significantly higher rates of COVID-related absence from work in Q2 2020 compared to Irish nationals. In addition, non-EU nationals have somewhat higher rates of COVID-related absence when models control for family status and education.

- Women are more vulnerable to absence for COVID-related reasons. In particular women who are Eastern European nationals are significantly more likely to experience COVID-related absences compared to those who are Irish nationals.

- $\quad$ Broadly consistent with the Labour Force Survey models, administrative statistics on Pandemic Unemployment Payment receipt from May to November 2020 show that around 28 per cent of PUP claimants were nonIrish nationals. This figure is significantly higher than the proportion of nonIrish nationals in the labour force in Q1 2020 before the pandemic hit (17.5 per cent). East European nationals were also more likely to receive payments under the Temporary Wage Subsidy Scheme (TWSS) relative to their share of employment, though not other non-Irish groups.

- Using a definition of essential services under Level 5 lockdown restrictions in Ireland, published in October 2020, we develop a measure of 'key workers' using the available data, building on an earlier definition from March used by Redmond and McGuinness (2020a). Who is counted as key or essential workers is evolving as government restrictions change and thus the nationality profile of the group as different sectors employ different proportions of non-Irish nationals.

- Using the definition based on Level 5 restrictions, Irish nationals (47 per cent) are significantly more likely to work in key jobs compared to non-Irish nationals (37 per cent) overall; however rates of key work vary across nonIrish national groups. African (42 per cent) and Asian (42 per cent) nationals are the most likely to be employed as key workers among non-Irish national groups with rates closer to that of Irish nationals (47 per cent). We also find that certain non-Irish national groups are overrepresented in key sectors.

- In general, Irish nationals (12 per cent) are significantly more likely to be employed in health and related sectors compared to non-Irish nationals (9 per cent). African ( 24 per cent) and Asian ( 26 per cent) nationals have significantly higher rates of employment in the health sector compared to Irish nationals and all other non-Irish national groups.

- Non-Irish nationals (11 per cent) are somewhat more likely to be employed as key workers in essential manufacturing compared to Irish nationals 
(9 per cent). Eastern European nationals (15 per cent) are significantly more likely to work in this sector compared to all other groups.

- Irish nationals (10 per cent) are significantly more likely to be employed as key workers in the education sector compared to non-Irish nationals (4 per cent).

- $\quad$ The report also briefly considers vulnerability of non-Irish nationals and ethnic minorities to the virus, using special tabulations on cases and deaths up to 24 November provided by the Central Statistics Office (CSO). These show that those of Black/Black Irish ethnicity, those of Asian ethnicity and Irish Travellers are overrepresented in COVID cases compared to their proportion in the population. Non-Irish nationals overall are slightly overrepresented in COVID cases compared to Irish nationals, relative to their proportion in the population. In general however, ethnic minority groups and non-Irish nationals are underrepresented in deaths from COVID, which is likely to be linked to their younger age profile. The CSO caution that these data are incomplete, and results may change over time.

- The survey and information used does not allow us to distinguish the impact of the COVID pandemic on asylum seekers and refugees, who have been found in other European countries to be a particularly vulnerable group (OECD, 2020b).

- The COVID pandemic is still evolving. This report is an early snapshot of the impact of the pandemic and how it varies by nationality. It is important that the potentially unequal impact of this crisis continues to be monitored so that policy responses can prevent the emergence of greater divisions in society. 



\section{CHAPTER 1}

\section{Introduction}

The COVID-19 pandemic has had far reaching consequences in almost every aspect of life, from direct effects on health to the economic consequences of lockdowns. Many countries worldwide introduced lockdowns (i.e. the closure of non-essential workplaces, educational establishments, and restrictions on movement/social interactions) to contain transmission of the virus. Following initial lockdowns most countries engaged in phased exits from lockdowns which included relaxed restrictions, this enabled many individuals to return to workplaces which had previously been closed. However, a large number of countries including Ireland had reintroduced lockdowns at the time of writing ${ }^{1}$ due to a second wave of the virus which inevitably had significant impacts on employment. As of 15 November, there were 53.7 million cumulative cases of COVID-19 globally (WHO, 2020), 68,686 cumulative confirmed cases of COVID in Ireland and 1,830 deaths. ${ }^{2}$ The majority of countries responded to the COVID crisis with lockdowns. These responses have differed in the timing and length of restrictions, however the restrictions imposed have largely been similar across countries. By 15 June roughly a third of workers globally lived in countries which required workplaces to close with the exception of essential occupations (ILO, 2020).

Overall restrictions generally increased between mid-March and mid-April, to the point where only workplaces classified as essential such as supermarkets were allowed to open in around half of $26 \mathrm{EU}$ countries $^{3}$ (Darmody et al., 2020). The Irish government initially recommended for employees to work from home where possible, before moving to close all workplaces bar those deemed essential in April and May, due to the increase of cases. The timing of reopening for businesses and services and the easing of restrictions were initially laid out in the Government's roadmap for recovery. The dates at which the country entered each phase have shifted throughout the pandemic, depending on the trends in case numbers. On 15 September the government published their plan for living with COVID Resilience and Recovery 2020-2021: Plan for Living with COVID-19, 2020 (Gov.ie, 2020) which consists of five levels. The lowest levels are activated when there are low rates of cases whereas the highest levels will be implemented to deal with high rates of incidences. This flexibility in responding to trends in cases has meant a series of changes to economic and social activity that have often been introduced at very short notice. As of midnight on 21 October, the country was placed in Level 5 of 
the Living with COVID Plan due to the increasing number of cases in October. The report examines the early impact of COVID-19 in Ireland on non-Irish nationals compared to Irish nationals, using the latest available data. It was produced as part of a programme of research on Integration and Equality, funded by Department of Children, Equality, Disability, Integration and Youth in line with the Migrant Integration Strategy 2017-2020, to complement the Monitoring Report on Integration 2020 (McGinnity et al., 2020a).

\subsection{COVID AND NON-NATIONALS IN THE LABOUR MARKET: INTERNATIONAL/IRISH EXPERIENCE}

Although the COVID-19 pandemic has affected entire populations, certain groups may be more vulnerable to the health and socio-economic issues associated with the pandemic. Since the emergence of the pandemic, migrants, foreign citizens and asylum seekers have been identified as particularly vulnerable to the direct and indirect effects of COVID-19. These can include economic issues (Fassani and Mazza, 2020), risk of infection, and derogatory or xenophobic language (ENAR, 2020; FRA, 2020a). Migrant workers may represent a particularly vulnerable workforce during the pandemic due to the nature of work in which they are typically employed. Previous research discussed below has found that migrants are overrepresented in both essential occupations and those which have been most affected by the crisis. Note some international literature compares migrants to native born; some compares foreign citizens to citizens of the country, and some compares different ethnic groups (see Section 1.2 for further details of how these differ).

\subsubsection{Essential workers}

Essential workers can loosely be defined as those who work in professions which are critical to the functioning of society during the COVID crisis, however detailed definitions of 'essential' or 'key' workers vary across time and countries. Although most countries introduced lockdowns due to COVID, the restrictions implemented varied in type and severity across countries. Even within countries, the classification of groups of workers as 'essential' has shifted over time. For example, the classification of essential workers in Ireland did not include teachers in the first lockdown but was expanded to include this group in the second lockdown. In addition, the analysis of essential workers may differ in cross-national research depending on the availability of labour force data.

Using data from the EU-LFS (2018), Fassani and Mazza (2020) highlight how migrant workers, specifically those born outside the EU, are overrepresented among key workers in low skilled professions in the EU. Migrant workers in the EU are also more likely to have temporary contracts (16 per cent more likely for EU migrants and 48 per cent more likely for non-EU migrants than the average value 
of 11 per cent) and less likely to work in occupations where it is possible to work from home (Fassani and Mazza, 2020). In addition, over half of migrant workers fall in the bottom four deciles of the income distribution. These contract and income differences remain even after accounting for differences in gender, age, occupation and educational achievement (ibid). Using a definition from March 2020, Redmond and McGuinness (2020a) find approximately 14 per cent of essential workers in Ireland are non-Irish nationals, with the highest concentration in transport and retail occupations (Redmond and McGuinness, 2020a). Essential workers in Ireland are more vulnerable to the effects of COVID-19 not just due to greater exposure to the virus but also due to the fact that many of these workers are older, live in deprived areas and suffer from chronic illnesses which make them more vulnerable to the virus (Walsh et al., 2020).

The pandemic has resulted in a call for increased numbers of migrant workers in health professions in many countries (IOM, 2020) to assist with staff shortages resulting from COVID. The call for increased migrant workers in healthcare professions includes migrant workers who are already in the country but whose qualifications are not recognised e.g. in Ireland and Germany (ibid). The increased need for healthcare workers is evident in Ireland, with the HSE asking all healthcare workers not in the public service to be 'on call for Ireland' (Be on call for IrelandHSE.ie, 2020). The World Bank has called for a number of short-, medium- and long-term interventions to address the effects of COVID-19 on migrants and remittances, one of which is to 'facilitate the recognition of skills of migrants and refugees in host countries to help with the shortage of skills' (KNOMAD, 2020). To address the need for healthcare workers in Ireland, the Department of Business, Economics and Innovation (DBEI) has advised that it has prioritised the processing of employment permit applications for medical professionals since mid-March (IOM Ireland, 2020).

\subsubsection{Job loss: international context}

In an American context, the economic crisis associated with the pandemic was found to disproportionately affect migrants. Between January and May 2020, migrants had a faster rise in unemployment rates than those born in the US (Capps et al., 2020). This high unemployment rate was found to be strongly related to the occupations in which these groups were employed with migrant workers more heavily concentrated in the professions hardest hit by the pandemic such as hospitality and retail. Research by Statistics Canada (LaRochelle-Côté and Uppa, 2020) conducted in early April found that immigrants (49 per cent) report significantly higher concern for their own and their families' health than Canadian-born respondents (33 per cent). Immigrant men (43 per cent) were also significantly more likely to believe that the COVID crisis would have a large impact on their personal finances than native men (27 per cent). 
Unemployment increases during COVID-19 have typically been much less dramatic in many European countries than the US or Canada, as many, including Ireland, put in place job retention schemes (see OECD, 2020a). ${ }^{4}$ However, there have been marked changes in the employment rate in European countries, and in most countries the fall in employment rates have been somewhat larger for migrants (OECD, 2020b). And while the crisis has been shown to negatively impact migrants in most host countries, the negative impact of the pandemic varies in severity across migrant groups. In Germany and Austria, the rise in unemployment was greater for EU migrants than native-born, but unemployment rates were much higher for non-EU migrants. By contrast in Spain the unemployment rate for EU citizens increased more than for non-EU citizens, and in Norway immigrant women from Central and Eastern Europe have been the hardest hit so far (OECD, 2020b). Data from Germany also suggest a more severe impact for migrant women than migrant men (Anger et al., 2020). Capps et al. (2020) highlight how the crisis has affected demographic groups differently in the US, with immigrant women reporting higher unemployment rates within almost every major ethnic group; Latina immigrants were the hardest hit by loss of employment. Research from Belgium (Baert et al., 2020) also finds that the fear of negative consequences on careers due to COVID-19 is higher in vulnerable groups such as migrants. In the study, migrants were found to have higher levels of fear surrounding losing their employment due to the pandemic or missing out on a promotion they believed they would have obtained if the COVID crisis had not occurred. However, it is not true that the labour market impact of COVID-19 has been greater for immigrants in all countries. In the Netherlands, for example, there is no evidence of a disproportionate impact of the pandemic on either the employment or unemployment of immigrants (OECD, 2020b).

\subsection{REPORT METHODOLOGY}

\subsubsection{Data sources and definitions}

The analysis in this report uses the most recent available data at the time of writing. Analysis of employment pre-pandemic and essential workers draws on Labour Force Survey (LFS) data from 2017 to 2019. Analysis of the impact of COVID on employment uses Q1 and Q2 data from the 2020 LFS. ${ }^{5}$ The Labour Force Survey is an expansive nationwide survey of private households, and thus excludes the homeless, those living in emergency accommodation, residential institutions and direct provision accommodation centres (see McGinnity et al., 2020a, Chapter 1 for discussion of the challenges of monitoring migration using survey data). Initial

$4 \quad$ People receiving payments such as the Pandemic Unemployment Payment do not strictly count as unemployed using the ILO definition, rather as temporarily laid off (but not actively seeking a new job. See Chapter 4 for further discussion).

5 Analysis of Q3 is not included in this report as these data had not yet been made available by the Central Statistics Office (CSO). 
interviews with respondents are completed face-to-face using Computer-Assisted Personal Interview (CAPI) software with follow up interviews completed over the phone. ${ }^{6}$ However due to COVID, face-to face interviews have been suspended and instead respondents receive an introductory letter before their first interview which is completed by telephone. ${ }^{7}$

Figures on the Pandemic Unemployment Payments (PUP) and Temporary Wage Subsidy Scheme (TWSS) were obtained from the CSO website and include data from the beginning of the pandemic through to early November.

Figures presented on deaths and cases come from the Computerised Infectious Disease Reporting (CIDR) database. ${ }^{8}$ These figures were matched to Census data from 2016 by the CSO to permit identification of non-Irish nationals and ethnic minorities as the CIDR database does not collect this information. Sixty-nine per cent of records were successfully linked and the following tables presents a statistical overview of these 49,169 confirmed cases and 1,145 deaths up to 24 November 2020. ${ }^{9}$ However, given that there are currently no other sources of data on this topic in Ireland, this information is still very informative. The census, in contrast to the Labour Force Survey, is a paper-based survey and includes all those resident in the State on the night of 24 April 2016. ${ }^{10}$ The census survey was available in 21 different languages; however the survey form itself could only be completed in English or Irish. ${ }^{11}$

This report classifies people primarily according to their nationality, not whether they were born abroad (migrant status). This nationality classification is consistent with the Monitoring Report on Integration 2020, which this publication accompanies. The advantage of using this measure is that Irish nationals (indeed all EU nationals) can live and work in Ireland without restriction, regardless of where they were born. In the Labour Force Survey, nationality was measured by asking respondents if they were an Irish citizen, if respondents answered no they were asked their country of citizenship. Non-Irish nationals are distinguished into categories to the extent that data permits, with the aim of maximising the number of groups where possible. In some cases, it was not possible to provide this detailed breakdown, so non-Irish are grouped together. A typical breakdown is the

https://www.cso.ie/en/methods/labourmarket/labourforcesurvey.

https://www.cso.ie/en/releasesandpublications/in/lfs/informationnote-implicationsofcovid-19onthelabourforcesurveyquarter22020update.

This is a database run by the Health Protection Surveillance Centre. See https://www.hpsc.ie/cidr.

In addition, there may be cases of COVID-19 undetected in any population group.

https://www.cso.ie/en/census.

https://www.cso.ie/en/media/csoie/methods/censusofpopulation/Census_2016_Quality_Report_rev_0918.pdf. 
following: UK, EU-East, EU-West and non-EU. ${ }^{12}$ In other cases the non-EU group is divided further to North America, Australia and Oceania, Africa, Asia and the Rest of the World (key workers analysis, Chapter 5).

Note nationality is different from migrant status, which indicates whether someone was born outside the Republic of Ireland. A significant proportion of those born abroad are Irish citizens - those who have naturalised, and those who are born abroad but Irish by descent. ${ }^{13}$ Deaths and cases are also presented by ethnicity. The measure of ethnicity used is based on the Census classification which aims to capture ethnic or racial background, albeit with some limitations and very broad categories - White, White Traveller, Other White background, Black, Asian, Other Ethnicity (including mixed Ethnicity). This is also distinct from nationality, as not all Irish nationals are White, nor are all non-Irish nationals minority ethnicity in fact most are White (see McGinnity et al., 2018a).

\subsubsection{Analysis}

A number of measures are used to try to capture the early-stage labour market impact in Chapter 4. As also noted by OECD (2020a), understanding the impact of COVID-19 in Ireland and evaluating evidence of this impact proves challenging using labour market measures and data available, which were designed with a different purpose in mind. We use three measures to assess early labour market impact of COVID-19 in Chapter 4. The first is the proportion receiving COVIDrelated welfare payments from administrative statistics.

The second is by modelling employment in both Q1 2020 (immediately prior to the pandemic) and Q2 2020 (pandemic) using LFS data, we investigate whether the change in employment between these two periods is greater for Irish or non-Irish nationals. We use the LFS measure of work status as our outcome, recoding this measure into a binary variable that lists those who are in work for pay and profit versus everyone else (absent from work, on lay-off, and those not working for other reasons). We estimate group differences using logistic regression, restricting analysis to those aged between 15 and 64 .

The third measure uses data from the Labour Force Survey Q2 2020 on respondents absent due to COVID. As before, we consider only those aged 15-64.

Data used to analyse deaths and cases by nationality draws on census data. The census measures nationality by directly asking respondents what their nationality is. Respondents had the option to answer Irish, other, or not stated. If respondents selected 'other' they had to write in their nationality. Respondents were required to select Irish and other if they were of dual nationality. Similar to the LFS, responses were then recoded into various categories.

13 Estimates from Census 2016 suggest around 37 per cent of those born abroad are Irish citizens. See McGinnity et al. (2020a) Appendix 4 for details. Those born in Northern Ireland are classified as born outside the Republic of Ireland but have Irish citizenship by birth. 
We isolate respondents who are absent due to COVID and compare this group to those in employment, unemployment and other inactivity using multinomial logistic regression.

One important feature of the COVID pandemic is that those who can work from home have been encouraged or instructed to do so. This 'remotability' is an important new distinction in the labour market that we expect has an influence on job loss. In the absence of detailed information on whether people have the ability to work from home or not in their job, such as Borjas and Cassidy (2020) use for the US, this report uses a proxy measure, based on whether people worked in an occupational group that had high pre-lockdown levels of working from home ${ }^{14}$ (many professionals) to others who did not (in service and sales occupations). Note this is not precise measure, nor does it tell us whether people are actually working from home, as we want to investigate the extent to which COVID-related job loss is linked to the potential of a job to be done from home. Occupations classified as high 'remotability' include managers, professionals and agricultural occupations. Occupations classified as low remotability include services and sales, craft and related and plant and machinery occupations: these occupations typically require the physical presence of a worker in their place of work. ${ }^{15}$ See Chapter 4 for further details of this measure.

Chapter 5 considers the role of non-Irish nationals as so-called 'key workers', based on Irish Labour Force Survey data prior to the pandemic. This is both to assess their contribution to the country's response to the pandemic in Ireland, as well as - for those on the 'front-line' such as healthcare workers - exposure to the virus (Gelatt, 2020). The definition draws on work done by Redmond and McGuinness ${ }^{16}$ (2020a) on essential employees in the early stages of the pandemic, based on the data available at the time. As the definition of what counts as essential has changed since then, we have expanded their definition to include workers that were previously deemed not essential but are classified as essential workers under the Level 5 lockdown restrictions, ${ }^{17}$ and call this group 'key workers'. The expanded definition, based on the list of essential services from October 2020, includes healthcare workers, those working in transport/retail, the education sector, utilities like electricity and gas, those working in certain key manufacturing sectors,

The Labour Force Survey asks how often respondents can work from home, and we use this measure to create an occupation level measure for the commonality of home working.

15 Of course, how 'remotable' a job is may be related to much wider range of factors than the occupation alone. Future research could usefully investigate this concept further by sector of activity, size of firm, contract type, seniority.

16 The definition of essential workers used by Redmond and McGuinness (2020) include: health professionals, health associate professionals, army affiliated workers, security and defence affiliated workers, health services workers, retail workers, and transport workers. 
and those in the construction sector. ${ }^{18}$ Crucially the definition of key workers only applies to employees and does not include self-employed: it also, by and large, does not include those who can work from home, as per government guidelines. ${ }^{19}$ Although we aim to include as many key workers as possible in the analysis, there are constraints to analysing such groups using existing data and definitions, and as such our definition may not be exact. This lack of precision is not a large factor in this analysis as we are less concerned with an exact estimate of key workers but rather the proportion of key workers who are non-Irish nationals.

\section{$1.3 \quad$ REPORT STRUCTURE}

The primary focus of this report is on the impact of COVID-19 on the labour market outcomes of non-Irish nationals compared to their Irish peers. Chapter 2 considers the vulnerability of non-Irish nationals to contracting COVID-19. The chapter examines the profile of COVID-19 deaths and cases as well as high risk living and working conditions. Chapter 3 presents pre-COVID data on employment by nationality for different sectors in the labour market, as well as a brief overview of the COVID-19 policy response in Ireland concerning the labour market and migration. Chapter 4 then considers the differences between Irish and non-Irish groups in terms of their employment patterns in Quarter 12020 and Quarter 2 2020, and how this is related to their demographic characteristics (such as age, family status), education and the nature of the jobs they work in. As discussed above, a number of labour market outcome measures are used to try to capture this early-stage impact. Chapter 5 then considers the role of non-Irish nationals as so-called 'key workers', based on Irish Labour Force Survey data prior to the pandemic. Chapter 6 summarises what we have learned and implications for migrant integration more broadly. In the remainder of this chapter we present the evidence and measures used to assess the impact of COVID-19 on Irish and non-Irish nationals in Ireland. 


\title{
CHAPTER 2
}

\section{Vulnerability of contracting COVID-19 among non-Irish nationals and ethnic minorities}

\begin{abstract}
There are a number of reasons why we might expect the vulnerability to COVID-19 of migrants or foreign citizens to be different to that of the host population (OECD, $2020 b)$. In general immigrant populations are younger, on average, than native populations, so not as susceptible to serious health consequences upon infection. This is also true in Ireland: very few non-Irish nationals are aged over 65 (less than 5 per cent of the non-Irish population, compared to over 14 per cent of the Irish population - see Table 2.2). Immigrants are often more likely to be income poor and living in deprivation in OECD countries. In Ireland in 2017-2018, the consistent poverty rate ${ }^{20}$ was somewhat higher for non-Irish nationals overall, particularly non-EU nationals, though EU-West and EU-East nationals do not differ in terms of consistent poverty risk from Irish nationals. Non-Irish nationals are not more likely to be deprived ${ }^{21}$ overall, though non-EU nationals have a higher deprivation risk (McGinnity et al., 2020a).
\end{abstract}

In many OECD countries, migrants are more likely to live in overcrowded dwellings and poor-quality housing. In previous Monitoring Reports on Integration (Integration Monitors) there was no significant difference in housing quality between Irish and non-Irish nationals overall (McGinnity et al., 2018a; Barrett et al., 2017). Barrett et al. (2017) did find that non-Irish nationals are more likely to live in overcrowded accommodation (8.4 per cent) than Irish nationals (3.9 per cent) but stressed that overcrowding in Ireland is very low compared to the EU average (around 20 per cent). In many countries migrants may be more likely to be front-line or essential workers, and less likely to be able to work from home (see Chapters 4 and 5 for a discussion of this in Ireland). IOM (2020) highlights how the pandemic intensifies existing gender dynamics generating gender-biased effects, such as the gendered division of labour, which disproportionately affect migrant and non-migrant women. According to the paper, women make up over 70 per cent of front-line health and social care workers globally meaning they are more likely to be on the front lines during the pandemic in professions such as nursing which make them particularly vulnerable to contracting COVID (ibid.). Research on COVID cases using data from the Computerised Infectious Disease Reporting Database matched to 2016 census data by the CSO shows that in Ireland nurses

Consistent poverty rate looks at households which are both at risk of poverty and materially deprived (McGinnity et al., 2020).

'The basic deprivation measure included 11 basic items (shoes, clothes, heating etc.) that are regarded as essential to fully participate in society with a minimum standard of living. A household is materially deprived if its members cannot afford to have two or more of these 11 items' (McGinnity et al., 2020). 
and midwives accounted for 6 per cent of COVID cases despite only making up 2 per cent of employees in April 2016 (CSO, 2020a). In addition, care workers and home carers were found to account for 4 per cent of cases but just 2 per cent of all employees in April 2016 (ibid).

International evidence on the vulnerability of migrants or foreign citizens to the virus is very limited, but available evidence does suggest that immigrants have been harder hit in terms of cases in Norway, Sweden, Denmark, Lisbon and Canada, though not in Italy (OECD, 2020a). This of course also highlights some difficulties with comparing cases cross-nationally, as there may be differences in testing regimes, as well as substantial differences between the migrant populations in terms of demographics and socio-economic circumstances (ibid.)

Other research has focused on inequalities between ethnic groups, who may or may not be born outside their country of residence or hold citizenship of the country they live in. Research from the UK has found that inequalities have been exacerbated by the COVID crisis with ethnic minorities more at risk of exposure to health risks and loss of income. The Black Caribbean population was found to have significantly higher COVID-related hospital deaths compared to the White British population (Platt and Warwick, 2020). These higher fatality rates may be partially explained by living in multi-generational households and higher levels of deprivation among some groups. However, even taking into account living conditions and deprivation, the risk of COVID-19 death was twice as large for Black men and 1.5 times greater for South Asian men compared to their White peers (White and Nafilyan, 2020). In the US, there is a higher COVID mortality among both the Hispanic population and particularly the Black population, even after controlling for pre-existing health conditions and socio-economic background (OECD, 2020a).

\subsection{COVID-19 IN IRELAND: PROFILE OF DEATHS AND CASES BY ETHNICITY AND NATIONALITY}

Very little is known about differences in the vulnerability of migrants, non-Irish nationals ${ }^{22}$ or ethnic minorities to the COVID-19 virus in Ireland. Information published by CSO as part of the COVID bulletin series ${ }^{23}$ does not currently distinguish different ethnic groups or nationalities, as there is insufficient information on the Computerised Infectious Disease Reporting database ${ }^{24}$ to do so. 
In the following tables, information from this database has been matched onto Census 2016 data, to permit identification of ethnic minorities and non-Irish nationals. In addition to presenting the proportion of cases (or deaths) by ethnic group/nationality, in both Tables 2.1 and 2.2 additional columns draw on Census 2016 data to show the proportion of the population in each ethnic or national group, and in Table 2.2 the proportion of each ethnic or national group that is over 65 , as this is where most of the more serious cases of COVID-19 have occurred. ${ }^{25}$

Table 2.1 shows that 21 per cent of the COVID-19 cases were among those who did not identify themselves as White Irish, whereas this group represents only 18 per cent of the total population, according to Census 2016. ${ }^{26}$ This suggests that ethnic minorities are over-represented in COVID-19 cases. While the 'Any Other White Background', registered the highest number of cases $(3,196)$, their total share of cases (6.5 per cent) is lower than their population share ( 9.5 per cent). This group classify themselves of White ethnicity but not Irish. ${ }^{27}$

This is not true for those of Black or Black Irish ethnicity, who make up 2.5 per cent of cases, compared to 1.4 per cent of the population. A more vulnerable group, given the data we have, is the Asian or Asian Irish, who made up 4.8 per cent of all cases but only 2.1 per cent of the population. This suggests that those of Asian ethnicity are 2.3 times as likely as White Irish to contract COVID-19 and those of Black ethnicity around 1.9 times as likely based on the data we have. ${ }^{28}$ One possible explanation is that these ethnic groups are more likely to be healthcare workers. This is not identified in the cases table, but we return to the issue in Chapter 5 while considering key workers. There could of course be other reasons for these differences too.

The ethnic group that seems most vulnerable to COVID-19 infection in Ireland with these data are Irish Travellers. Irish Travellers make up 1.8 per cent of COVID cases but only 0.7 per cent of the population. The figures in Table 2.1 suggest Irish Travellers are 2.6 times as likely to contract COVID-19 than the White Irish population. One possible explanation is that Travellers are much more likely to live

Promotion Board and the Department of Health. These data are provided to the CSO by the HPSC. The CIDR database does collect information on ethnicity and nationality but it is of insufficient quality to publish regularly. best representative source of information on ethnic groups in Ireland. Nationality information also draws on Census 2016 data for consistency. to measure diversity and the complex lived reality of race and ethnicity. The result is racial/ethnic 'meta-categories', which are limited in both number of meta-categories and explanatory power. See also McGinnity et al., 2018b for discussion. 
in overcrowded accommodation than non-Travellers in Ireland (Watson et al., 2017). Using CIDR data matched to census data, the CSO (2020a) showed that of the households who had a confirmed COVID case, 19 per cent were in overcrowded homes. The prevalence of underlying health conditions is also much higher among the Traveller population than among non-Travellers (Watson et al., 2017; FRA, 2020b; 2020c). These and other potential explanations would require further investigation.

TABLE 2.1 PROFILE OF COVID-19 CASES BY ETHNICITY AND NATIONALITY IN IRELAND ${ }^{1}$

\begin{tabular}{|c|c|c|c|c|}
\hline \multicolumn{2}{|c|}{ Ethnicity } & Cases $^{1}$ & $\%$ of Cases & $\begin{array}{l}\text { \% of Population } \\
(2016)^{2}\end{array}$ \\
\hline \multicolumn{2}{|c|}{ White Irish } & 38,934 & 79.2 & 82.2 \\
\hline \multicolumn{2}{|c|}{ White Irish Traveller } & 885 & 1.8 & 0.7 \\
\hline \multicolumn{2}{|c|}{ Any Other White Background } & 3,196 & 6.5 & 9.5 \\
\hline \multicolumn{2}{|c|}{ Black or Black Irish } & 1,229 & 2.5 & 1.4 \\
\hline \multicolumn{2}{|c|}{ Asian or Asian Irish } & 2,360 & 4.8 & 2.1 \\
\hline \multicolumn{2}{|c|}{ Other incl. Mixed Background } & 639 & 1.3 & 1.5 \\
\hline \multicolumn{2}{|c|}{ Not Stated } & 1,926 & 3.9 & 2.6 \\
\hline \multicolumn{2}{|c|}{ Total } & 49,169 & 100.0 & 100.0 \\
\hline \multicolumn{2}{|c|}{ Nationality } & Cases $^{1}$ & $\%$ of Cases & $\%$ of Population ${ }^{3}$ \\
\hline \multicolumn{2}{|c|}{ Irish } & 43,022 & 87.5 & 87.0 \\
\hline \multicolumn{2}{|c|}{ Non-Irish } & 5,950 & 12.1 & 11.4 \\
\hline \multicolumn{2}{|c|}{ Not Stated incl. No Nationality } & 197 & 0.4 & 1.5 \\
\hline \multicolumn{2}{|c|}{ Total } & 49,169 & 100.0 & 100.0 \\
\hline $\begin{array}{l}\text { Source: } \\
\text { Notes: }\end{array}$ & \multicolumn{4}{|c|}{$\begin{array}{l}\text { CSO CIDR data matched to } 2016 \text { census data. } \\
\text { 1. Table includes data as of } 25 \text { November } 2020 \text { for events created on CIDR (Computerised Infectious Disease Reporting) up to } \\
\text { midnight on Tuesday } 24 \text { November } 2020 \text {. This was matched to data from Census of Population } 2016 \text { by CSO, under the auspices } \\
\text { of the Statistics Act } 1993 \text { and in compliance with all relevant data protection legislation, for the purpose of the CSO Frontier Series } \\
\text { Output } A \text { Profile of COVID-19 in Ireland - Using Census } 2016 \text { Household Data to Analyse COVID-19 Cases from March to November } \\
\text { 2020. The match rate between CIDR and Census of Population data was } 69 \text { per cent, total population size (number of cases) in } \\
\text { CIDR as of } 25 \text { November was } 71,187 \text {. (See also CSO } 2020 \text { a for further details). }{ }^{29} \\
\text { 2. Percentage of population for ethnicity was taken from the Census of Population } 2016 \text { Statbank table E8001. } \\
\text { 3. Percentage of population for nationality was taken from the Census of Population } 2016 \text { Statbank table E7020. }\end{array}$} \\
\hline
\end{tabular}

The experiences of non-Irish nationals are distinct from those of ethnic minorities and the overall pattern a little different. For nationality, the figures in Table 2.1 only distinguish Irish, non-Irish and nationality not stated (including no nationality). ${ }^{30}$ Here we see that non-Irish nationals made up 12.1 per cent of reported COVID-19 cases, which is slightly higher than 11.4 per cent, their share of the population in 2016. ac19/aprofileofcovid-19inireland-usingcensus2016householddatatoanalysecovid19casesfrommarchtonovember2020/methodology. 
Table 2.2 presents the proportion of COVID-19 deaths by ethnicity and nationality. For ethnicity, the story on deaths is rather different than for COVID-19 cases. 92 per cent of deaths occurred among White Irish nationals, compared to 82 per cent of the population identifying as White Irish, suggesting that overall ethnic minorities are less vulnerable to deaths from COVID-19. For White Irish Travellers, Black/Black Irish, or Asian/Asian Irish there were fewer than five deaths, if any, up until 24 November, so these are not reported. ${ }^{31}$ The 'any other White background' group made up 2.3 per cent of deaths but 9.5 per cent of the population. Part of the lower death figures is likely to relate to the different age profiles of the groups. Between March and November 2020, 92 per cent of COVID-19 deaths were among those aged over 65 years old (CSO, 2020b). Table 2.2 shows that less than 3 per cent of the ethnic minority groups are aged over 65 , this is true of just over 10 per cent of the White Irish population. The younger age profile of ethnic minority groups is likely to explain the lower proportion of deaths as a proportion of cases recorded in the final column in Table 2.2 also.

For nationality the pattern of deaths is similar to that for ethnicity. Table 2.2 shows that 5.2 per cent of all deaths have been to non-Irish nationals, where non-Irish nationals make up over 11 per cent of the population. As with ethnic minorities, the age structure may play a role in understanding COVID-19 deaths. Less than 5 per cent of the non-Irish population are under 65, compared to almost 15 per cent of the Irish population. Self-rated health is also typically higher among nonIrish nationals, with the exception of UK nationals, once again likely to be linked to the younger age profile of non-Irish nationals in Ireland (McGinnity et al., 2020a). It should be noted here that both the overall proportion of the population that is of an ethnic minority background and the total number of deaths in Ireland reported in Table 2.2 is small, and patterns may change over time. 


\begin{tabular}{|c|c|c|c|c|c|}
\hline Ethnicity & Deaths $^{1}$ & $\%$ of Deaths & $\begin{array}{c}\% \text { of } \\
\text { Population } \\
(2016)^{2}\end{array}$ & $\begin{array}{c}\text { \% Aged over } \\
65(2016)^{2}\end{array}$ & $\begin{array}{c}\text { Deaths as a } \\
\text { proportion of } \\
\text { Cases (\%) }\end{array}$ \\
\hline White Irish & 1,056 & 92.0 & 82.2 & 10.2 & 2.7 \\
\hline White Irish Traveller & $*$ & $*$ & 0.7 & 1.7 & $*$ \\
\hline Any Other White Background & 26 & 2.3 & 9.5 & 2.9 & 0.8 \\
\hline Black or Black Irish & $*$ & $*$ & 1.4 & 0.6 & $*$ \\
\hline Asian or Asian Irish & 5 & 0.4 & 2.1 & 1.2 & 0.2 \\
\hline Other incl. Mixed Background & $*$ & $*$ & 1.5 & 2.6 & $*$ \\
\hline Not Stated & 49 & 2.6 & 2.6 & 11.7 & 2.5 \\
\hline Total & 1,145 & 100.0 & 100 & 9.1 & 2.3 \\
\hline Nationality & Deaths $^{1}$ & $\%$ of Deaths & $\begin{array}{c}\% \text { of } \\
\text { Population }^{3}\end{array}$ & $\%$ over $65^{3}$ & $\begin{array}{c}\text { Deaths as } \\
\text { proportion of } \\
\text { cases }\end{array}$ \\
\hline Irish & 1,057 & 92.3 & 87.0 & 14.4 & 2.5 \\
\hline Non-Irish & 59 & 5.2 & 11.4 & 4.8 & 1.0 \\
\hline Not Stated incl. No Nationality & 29 & 2.5 & 1.5 & 14.7 & 14.7 \\
\hline Total & 1,145 & 100.0 & 100.0 & 13.3 & 2.3 \\
\hline
\end{tabular}

Source: $\quad$ CSO CIDR data matched to 2016 census data.

Notes: $\quad$ 1. Table includes data as of 25 November 2020 for events created on CIDR (Computerised Infectious Disease Reporting) up to midnight on Tuesday 24 November. This was kindly matched to data from Census of Population 2016 by CSO, under the auspices of the Statistics Act 1993 and in compliance with all relevant data protection legislation, for the purposes of this report. The match rate between CIDR and Census of Population data was 69 per cent, total population size (number of cases) in CIDR as of 25 November was 71,187 . * Indicates a cell number $<5$ or a cell number $<5$ can be identified so is suppressed in the table. This explains why the total of deaths by ethnicity is higher than sum of deaths by ethnic groups. Data are defined by date of death.

2. Percentage of population and percentage of population aged over 65 for ethnicity was taken from the Census of Population 2016 Statbank table E8001.

3. Percentage of population and percentage of population aged over 65 for nationality was taken from the Census of Population 2016 Statbank table E7020: Population Usually Resident and Present in the State 2011 to 2016 by Single Year of Age, Sex, Nationality and Census Year.

There are a number of important limitations with these figures. As noted, only 69 per cent of COVID-19 deaths and cases could be matched to an ethnic or national identifier. We cannot rule out that the 31 per cent of cases not matched might display a rather different pattern of COVID exposure. In addition, it seems likely that the match rate was higher for Irish nationals than non-Irish nationals, given that more non-Irish nationals may have come to Ireland since 2016 than Irish nationals. This could mean that these figures are an underestimate of COVID cases among the non-Irish population vis-à-vis the Irish population, although it is not possible to quantify this using the data we have. More generally, COVID-19 cases may go undetected in the population. This will primarily affect the patterns presented here if there are systematic differences between ethnic or national groups in virus detection. Some recent research on perceptions of COVID testing in Ireland suggests that there may be differences in Irish and non-Irish nationals in 
their perceptions of COVID testing. ${ }^{32}$ Timmons et al. (2020) find that compared to Irish nationals, non-Irish members of the public believe GPs will be less likely to recommend a test, that they need to pay for a test (when in reality it is free), and that results will be less accurate. This may also mean that non-Irish nationals may be less likely to get a test if they have symptoms and thus cases will be underestimated among non-Irish nationals compared to Irish nationals, but we have no clear evidence of this. Differences in propensity to get testing, if this is the case, should, at least in principle, be less of an issue for the COVID deaths. In terms of treatment, access to healthcare in Ireland does not depend on nationality, length or nature of residence, or even, in terms of COVID-19 at least, on financial resources/having private health insurance (see McGinnity et al., 2020a). Finally, these cases and deaths relate to the period up to 24 November. Additional cases and cases and deaths, when reported, could have different characteristics, and a similar table in mid-2021 could look very different.

\subsection{COVID-19 IN IRELAND: HIGHER RISK LIVING AND WORKING CONDITIONS}

\subsubsection{Direct provision}

While they make up a small proportion of non-Irish nationals overall (see McGinnity et al., 2020a), those living in direct provision accommodation centres may be among the most vulnerable to the effects of the pandemic in Ireland. As Gusciute (2020) notes, social distancing and cocooning is virtually impossible in residential settings such as direct provision accommodation centres, as residents often share spaces such as kitchens and bathrooms. In Germany, researchers found that compared with other forms of housing, collective housing for asylum seekers increased the risk of COVID-19 transmission by 17 per cent (though this varied substantially across settings (University of Bielefeld, 2020). The Irish government has introduced measures to relocate some of those living in direct provision, however social distancing is often still not possible with many individuals sharing rooms. A report published by the Irish Refugee Council (2020) found that half of respondents in the direct provision system are unable to social distance from others and 42 per cent share a room with someone who is not a family member. The lack of space to allow for social distancing makes those living in direct provision accommodation centres vulnerable to the virus; this vulnerability is evident with outbreaks of the virus reported in centres in Kerry (Lucey, 2020) and Kildare (Fletcher, 2020). The final report published by the Oireachtas Special Committee on COVID-19 Response notes that the need to provide individual unit and family unit accommodation to those in direct provision accommodation centres requires further examination by the Joint Committee on Children, Disability, Equality and 
Integration (Houses of the Oireachtas, 2020). As of 27 November, 4 per cent of cumulative confirmed cases linked to COVID-19 outbreaks ${ }^{33}$ were associated with residential institutions, this had dropped from highs of 8 per cent seen throughout the summer (CSO, 2020b). The definition of residential institutions used here includes not only direct provision accommodation centres but also centres for disabilities, prisons, centres for older people, mental health facilities and homeless facilities. It is important to note that direct provision residents make up a small percentage of those in residential institutions. Looking at direct provision specifically there were 235 cases associated with 21 outbreaks in direct provision accommodation centres up to 4 August (Donnelly, 2020).

Since June 2018, international protection applicants who have been waiting for a first-instance decision on their application for a specific period are permitted to access the labour market in Ireland. ${ }^{34}$ Protection applicants who continue to work during the pandemic in essential occupations are vulnerable to contracting the virus. Protection applicants who are permitted to work but have lost their job during the pandemic were not entitled to the Pandemic Unemployment Payment (PUP) until 6 August when PUP became available for protection applicants living both in and outside direct provision (Department of the Taoiseach, 2020). The eligibility of protection applicants for PUP was a significant step both to alleviate the economic effects of the virus on this group as well as ensuring that these workers could 'prioritise the health and safety of themselves and their communities' (ibid) (see Section 3.2.1).

\subsubsection{Meat processing plants}

As of 4 August, there were 24 outbreaks associated with meat processing plants in Ireland (Donnelly, 2020). Research conducted by the European Centre for Disease Prevention and Control (ECDC, 2020) across 15 EU/EEA countries and the UK between April and early July found that Ireland had the highest levels of cases associated with food production including agriculture. Further COVID-19 outbreaks occurred in meat processing plants in Kildare in August. In Ireland, meat processing is dominated by migrant labour, as in many other countries; the meat sector is an important export sector in Ireland, but workers' wages are low (MRCl, 2020). In 2018 employment permit regulations changed to allow non-EU nationals to apply for permits to work in the sector, but many of the non-Irish workers in the sector

Outbreaks are defined as two or more cases in the same location and time (CSO, 2020c).

International protection applicants are those who have applied for but not yet been granted refugee status, or another protection status (see McGinnity et al., 2020a Box 1.1 for a brief description of different protection statuses in Ireland). Since June 2018, over 5,500 permissions to access the labour market have been issued, including over 4,200 permissions to residents of direct provision accommodation centres (see https://www.gov.ie/en/press-release/59532-minister-ogormanand-minister-mcentee-publish-the-report-by-the-advisory-group-on-direct-provision-and-announce-a-reduction-in-thewaiting-period-for-international-protection-applicants-to-access-work/). Note until recently a permission was valid for six months and any individual can have multiple permissions, and not all applicants are eligible to apply for one (e.g. if they have not been waiting for a decision for the required amount of time). 
are still nationals of other EU states. Combining figures from Census 2016 and more recent employment permits data suggest that just under 60 per cent of people employed in meat production are non-Irish (ibid). Of this 60 per cent, over half (56 per cent) are from other EU countries, mostly Eastern Europe, and another 44 per cent from non-EU countries. As only 20 per cent of this workforce have sick pay schemes, the Oireachtas Special Committee on COVID-19 Response has referred the need for sick pay schemes to be made available to all of this workforce to the Joint Committee on Enterprise, Trade and Employment (Houses of the Oireachtas, 2020). Using data from 2016, Privalko et al. (2020) find self-reported English language skills of meat processing workers are much lower than in the nonIrish population overall. Poor working conditions, including pressure to work at speed on production lines, were a central theme of a recent survey of migrant workers in the meat sector in Ireland (MRCl, 2020). According to the ECDC (2020), risk factors in this industry associated with contraction of COVID include working in confined or close spaces and lack of social distancing. In other European countries, living in overcrowded accommodation is common among workers in the sector, but there is no clear evidence in Ireland that that is the case (Privalko et al., 2020; $\mathrm{MRCl}, 2020$ ). 



\section{CHAPTER 3}

\section{Employment pre-pandemic, policy responses to COVID and migration trends}

\subsection{EMPLOYMENT OF NON-IRISH NATIONALS PRIOR TO THE PANDEMIC}

Previous research on the labour market in Ireland has found high employment rates among non-Irish nationals. In 2019, both employment and participation rates among working-age non-Irish nationals were higher than for Irish nationals. Up until 2018, unemployment rates of non-Irish were slightly higher, but by 2019 , unemployment rates were not significantly different between the two groups (McGinnity et al., 2020a).

There was, however, substantial variation in employment rates between non-Irish groups, depending on their region of origin. Most migration to Ireland from within the EU (excluding the UK) is labour migration, and EU nationals have very high employment rates; Eastern Europeans, 76 per cent, and West Europeans, 80 per cent. UK nationals have similar employment rates (72 per cent) to Irish nationals (69 per cent). Those from outside the EU have lower employment rates, partly because of high student migration among this group (see McGinnity et al., 2020a), with employment rates among Asian nationals at 61 per cent, North American/Australia/Oceania nationals 62 per cent, the 'Rest of the World' 64 per cent, and Africa 60 per cent. By 2019, only African nationals had higher unemployment rates (12 per cent) than Irish nationals ( 5 per cent); no other significant differences in unemployment rates between Irish and non-Irish national groups were found (McGinnity et al., 2020a).

Of course, as well as differences in employment rates, there are also differences in the sectors in which Irish and non-Irish nationals work. Sector refers to the economic activity of the organisation someone works for, based on the NACE international classification scheme (Table 3.1). ${ }^{35}$ This is important because in the COVID pandemic, as is typical in recessions, job loss is not evenly distributed across sectors of activity, with some sectors being harder hit than others. Essential workers are also often defined by the nature of the activity their organisation performs, so understanding which types of work non-Irish nationals do will help to understand the contribution of non-Irish nationals to essential work during the pandemic. 
Figure 3.1 shows the sector breakdown for Irish and non-Irish nationals. Irish nationals are significantly more likely to work in agriculture, public administration, education and human health and social work activities, whereas non-Irish nationals are significantly more likely to work in industry (manufacturing), accommodation and food, information and communication and administrative and support sectors. However, the grouping of all non-Irish nationals hides divergent effects for different non-Irish groups. Table 3.1 shows the sector breakdown among different non-Irish groups.

\section{FIGURE 3.1 IRISH AND NON-IRISH NATIONALS SECTOR BREAKDOWN Q1 2018 AND 2019}

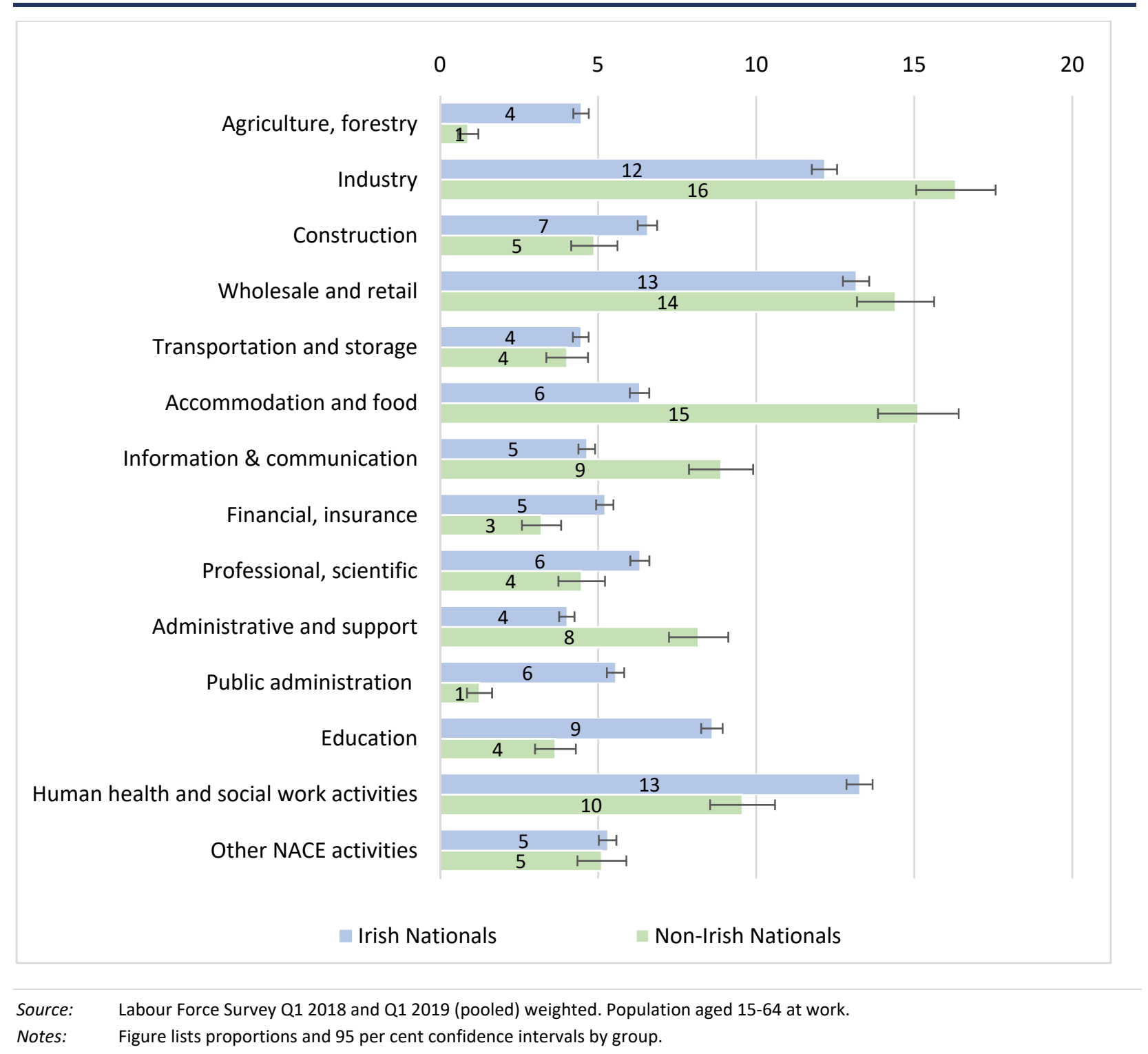

Although Figure 3.1 shows that Irish nationals (13 per cent) are significantly more likely to work in human health and social work compared to non-Irish nationals, from Table 3.1 we can see that participation in this sector differs across nationality groups. Whilst participation in this sector is significantly lower for Eastern (8 per cent) and Western European nationals ( 6 per cent), UK (13 per cent) and non-EU nationals 
(15 per cent) have similar or higher levels of participation in this sector compared to Irish nationals. Overall most migrant groups are prevalent in the industry sector with higher rates of participation compared to Irish nationals with the exception of the nonEU group. Both Eastern European nationals (16 per cent) and those from the Rest of the World group (20 per cent) have high participation rates in the accommodation and food sector where few Irish workers are found (6 per cent).

TABLE 3.1 IRISH AND NON-IRISH NATIONALS SECTOR BREAKDOWN Q1 2018 AND 2019 (LFS)

\begin{tabular}{|l|r|r|r|r|r|r|}
\hline Sector & Ireland & $\begin{array}{l}\text { United } \\
\text { Kingdom }\end{array}$ & EU-West & EU-East & Non-EU & Overall \\
\hline Agriculture, forestry & 4.5 & 1.4 & 0.2 & 1.0 & 0.9 & 3.9 \\
\hline Industry & 12.2 & 14.2 & 14.5 & 21.4 & 9.3 & 12.8 \\
\hline Construction & 6.6 & 5.4 & 1.3 & 7.2 & 2.5 & 6.3 \\
\hline Wholesale and retail & 13.2 & 15.0 & 8.8 & 18.4 & 10.3 & 13.4 \\
\hline Transportation and storage & 4.5 & 3.4 & 3.5 & 5.3 & 2.5 & 4.4 \\
\hline Accommodation and food & 6.3 & 9.4 & 11.4 & 15.8 & 20.2 & 7.8 \\
\hline Information \& communication & 4.6 & 6.2 & 21.0 & 3.7 & 12.5 & 5.3 \\
\hline Financial, insurance & 5.2 & 4.8 & 6.4 & 1.4 & 3.5 & 4.9 \\
\hline Professional, scientific & 6.3 & 6.9 & 6.5 & 3.1 & 4.2 & 6.0 \\
\hline Administrative and support & 4.0 & 5.0 & 7.2 & 9.7 & 8.0 & 4.7 \\
\hline Public administration & 5.6 & 3.3 & 0.9 & 0.8 & 1.1 & 4.8 \\
\hline Education & 8.6 & 6.1 & 6.1 & 1.5 & 4.4 & 7.8 \\
\hline Human health and social work activities & 13.3 & 12.9 & 8.4 & 5.9 & 15.0 & 12.7 \\
\hline Other NACE activities & 5.3 & 6.12 & 3.6 & 5.0 & 5.7 & 5.3 \\
\hline Total & 100 & 100 & 100 & 100 & 100 & 100 \\
\hline
\end{tabular}

Source: $\quad$ Labour Force Survey (Q1 2018, Q1 2019) provided by the ISSDA. Accessed via the Irish Social Science Data Archive: www.ucd.ie/issda.

Notes: $\quad$ Population aged 15-64 at work. Sectors of interest are highlighted. NATIONALS

The government introduced a number of responses to COVID at the beginning of the pandemic, most notably the closure of schools, colleges and childcare facilities on 12 March, the closure of all non-essential shops on 24 March, the request for individuals to stay at home, and the introduction of the Pandemic Unemployment Payment and Temporary Wage Subsidy Scheme.

\subsubsection{Labour market supports}

Due to the closure of non-essential services on 24 March and its subsequent effect on unemployment levels and incomes, the government introduced the Pandemic Unemployment Payment (PUP) and the Temporary Wage Subsidy Scheme (TWSS) which are available to both Irish and non-Irish nationals. In November 2020 the 
monthly unemployment rate stood at 7.5 per cent ${ }^{36}$ however according to the CSO (2020c) the unemployment rate could be as high as 21 per cent if all claimants of the Pandemic Unemployment Payment were included with unemployed. ${ }^{37}$

PUP is available to both employees and the self-employed who lost their job on or after 13 March 2020 due to the pandemic. Individuals can apply for PUP if they:

- $\quad$ are aged between 18 and 66 years old; and

- $\quad$ currently living in the Republic of Ireland; and

- have at least one PRSI contribution in the four weeks before claiming PUP or be in insurable self-employment;

- have lost their job due to the COVID-19 pandemic; or

- have been temporarily laid off due to the COVID-19 pandemic; and

- $\quad$ worked in the Republic of Ireland or were a cross border frontier worker; and

- $\quad$ are not in receipt of any employment income.

(COVID-19 Pandemic Unemployment Payment, 2020)

The payment also applies to students including international students, part-time workers, and non-EU workers who have lost employment due to the pandemic, as long as the worker had paid a minimum amount of social welfare (PRSI) contributions or had been on an employer's payroll. ${ }^{38}$ As well as being allowed to apply for PUP if their jobs were lost due to COVID, international students (specifically those with a Stamp 2 permission) ${ }^{39}$ who continued to work throughout the pandemic were allowed to work up to 40 hours a week (the limit for out of term working hours) whilst their educational institution was closed due to COVID (EMN, 2020a).

In addition to the introduction of PUP, the Temporary Wage Subsidy Scheme (TWSS) was introduced on 26 March 2020 and was subsequently replaced by the Employment Wage Subsidy Scheme (EWSS) on 1 September. These schemes enable employers to pay their workers that are on temporary layoff due to the pandemic and therefore allow employees to retain their job. Employers qualify if they can prove that they have lost at least a quarter of their trade due to the pandemic (Temporary COVID-19 Wage Subsidy Scheme, 2020). The rates of payment associated with PUP and TWSS/EWSS have changed throughout the pandemic. At the time of writing (November 2020), both PUP and EWSS both had maximum payments of $€ 350$ per week and minimum

Those in receipt of COVID-19 income supports are not classified as unemployed in the CSO's standard monthly unemployment rate.

https://www.cso.ie/en/releasesandpublications/er/mue/monthlyunemploymentnovember2020.

The payment is not payable with respect to loss of informal employment where no records exist.

http://www.inis.gov.ie/en/inis/pages/registration-stamps\#stamp2. 
payments of $€ 203$ per week. These rates are expected to continue until 31 January 2021 (COVID-19 Pandemic Unemployment Payment, 2020; Employment Wage Subsidy Scheme, 2020).

Although some employers provide sick pay to their employees, it is not a legal requirement in Ireland. To address loss of income due to COVID symptoms or diagnosis, the government introduced the COVID-19 Enhanced IIIness Benefit on 9 March 2020 which is expected to be in place until 31 March 2021. Individuals who have been at work may apply for this benefit if they are suspected of having COVID-19 and are asked to self-isolate by a doctor or the Health Service Executive or if they have been diagnosed with the virus. All workers, including those from non-EU/EEA countries, are eligible for the benefit if they satisfy these requirements. ${ }^{40}$ The personal rate of benefit payment is $€ 350$ per week. ${ }^{41}$

\subsubsection{Migrant-specific policy response}

In order to reassure migrants in an irregular situation that they could access COVIDrelated treatment or social supports without fear of deportation, the Department of Justice advised that it would not seek information relating to immigration status from the Health Service Executive (HSE) or the Department of Employment and Social Protection (DEASP). Even with this reassurance, it could be that migrants in an irregular situation may be reluctant to seek treatment or access social support and may be a particularly vulnerable group in the COVID-19 pandemic. ${ }^{42}$ The HSE Social Inclusion Department has also provided online resources giving detailed information about COVID including posters and booklets in 29 languages to make the information more readily accessible for those whose first language is not English (IOM Ireland, 2020).

Aside from the general policy response to the pandemic, the Department of Justice also introduced a number of measures to address the effect of the pandemic on (non-EU) migrants' and asylum seekers' visas, permissions and permits. The measures discussed below represent a few of the necessary actions taken by the government. More information on these and additional measures can be found on the department's recently published FAQ document on the impact of COVID-19 on Immigration and International Protection. ${ }^{43}$ Note most non-Irish nationals in Ireland

Individuals qualify to get the benefit if they: are aged between 18 and 66; have a Certificate of incapacity for work from a doctor or have a text or letter notification from the HSE; are employed or self-employed and worked in the four weeks prior to the diagnosis or requirement to self-isolate, and have a current contract of employment, if an employee (COVID-19 enhanced IIIness Benefit, 2020).

41 Eligibility to apply for the COVID-19 Enhanced IIIness benefit was extended to those living in direct provision from 6 August 2020 (IOM Ireland, 2020).

42 In addition if their employment is informal they will not be entitled to COVID-related employment supports like the PUP or TWSS.

43 http://www.inis.gov.ie/en/INIS/Immigration-Service-Delivery-Covid-19-FAQ4.pdf/Files/Immigration-Service-Delivery-Covid-19FAQ4.pdf. 
are nationals of other EU countries or the UK - almost three-quarters of them in 2019 - so these measures would not apply. ${ }^{44}$

Measures to address immigrant registration and permissions included five automatic extensions of immigration permissions which were due to expire. The fifth extension, which is expected to be the final extension granted by the Department of Justice, applies to all permissions due to expire between 20 September 2020 and 20 January 2021.45

Regarding visas, the Immigration Service Delivery began a limited resumption of visa services on 22 June. During the initial resumption phase, the immigration service delivery is only dealing with Long-term ' $D$ ' Visa applications as well as Emergency/ Priority visas (ibid).

All interviews with the International Protection Office are currently postponed, however the IPO is providing a limited service to new applicants. Individuals whose Temporary Residence Certificates (TRC) were due to expire between 27 March and 20 June were automatically issued new cards. ${ }^{46}$ In order to prevent the spread of COVID among residents of the accommodation system for protection applicants, public health advice (including translations) were provided to all accommodation centres, and residents were moved from emergency accommodation to dedicated accommodation centres. Measures were also introduced in direct provision centres to prevent the spread of COVID which included self-isolation facilities within the centres as well as offsite self-isolation facilities.

It is likely that the pandemic has had a substantial effect on migration patterns in Ireland. The CSO's population and migration estimates were published in August 2020, but only cover the period until end April 2020. EU and OECD countries have introduced a wide range of measures to manage residence permits and migrant unemployment during the pandemic (EMN, 2020b). OECD (2020a) shows a dramatic fall in new residence permits issued in the period March-June 2020 in OECD countries, and 2020 is projected to be a historic low for international migration in the OECD. EU nationals in Ireland. area was expedited due to COVID-19 (New migration and asylum measures introduced in response to COVID-19, European Migration Network, 2020). 


\section{CHAPTER 4}

\section{Are non-Irish nationals more vulnerable to the labour market impact of COVID-19?}

In this chapter we explore the risks of different non-Irish groups to COVID-related lay-off and job loss. As previous research has demonstrated, non-Irish nationals are not a homogenous group and depending on country and region of origin, face different opportunity structures and levels of discrimination (McGinnity et al., $2018 \mathrm{~b}$; 2020b). Therefore, it is important, in so far as the data allow, to differentiate between different non-Irish groups.

\subsection{PATTERNS OF JOB LOSS}

Workplace closures and job losses due to the pandemic have not been uniform across the economy (see Figure 4.1). Those in the hospitality sector, the arts and certain parts of the retail sector have been particularly hard hit. Pre-COVID patterns show that non-national workers are over-represented in some sectors that have been particularly exposed to job loss, such as accommodation and food where non-Irish nationals are more than twice as likely to work (see Chapter 3). The unemployment figures have also highlighted that young people have been disproportionately affected (CSO, 2020d; McQuinn et al., 2020); and in Ireland, where inward migration is a relatively recent phenomenon, non-Irish nationals tend on average to be younger than the native population (McGinnity et al., 2020a).

\section{FIGURE 4.1 DECLINE IN EMPLOYMENT BY SECTOR BETWEEN Q1 AND Q2 2020}

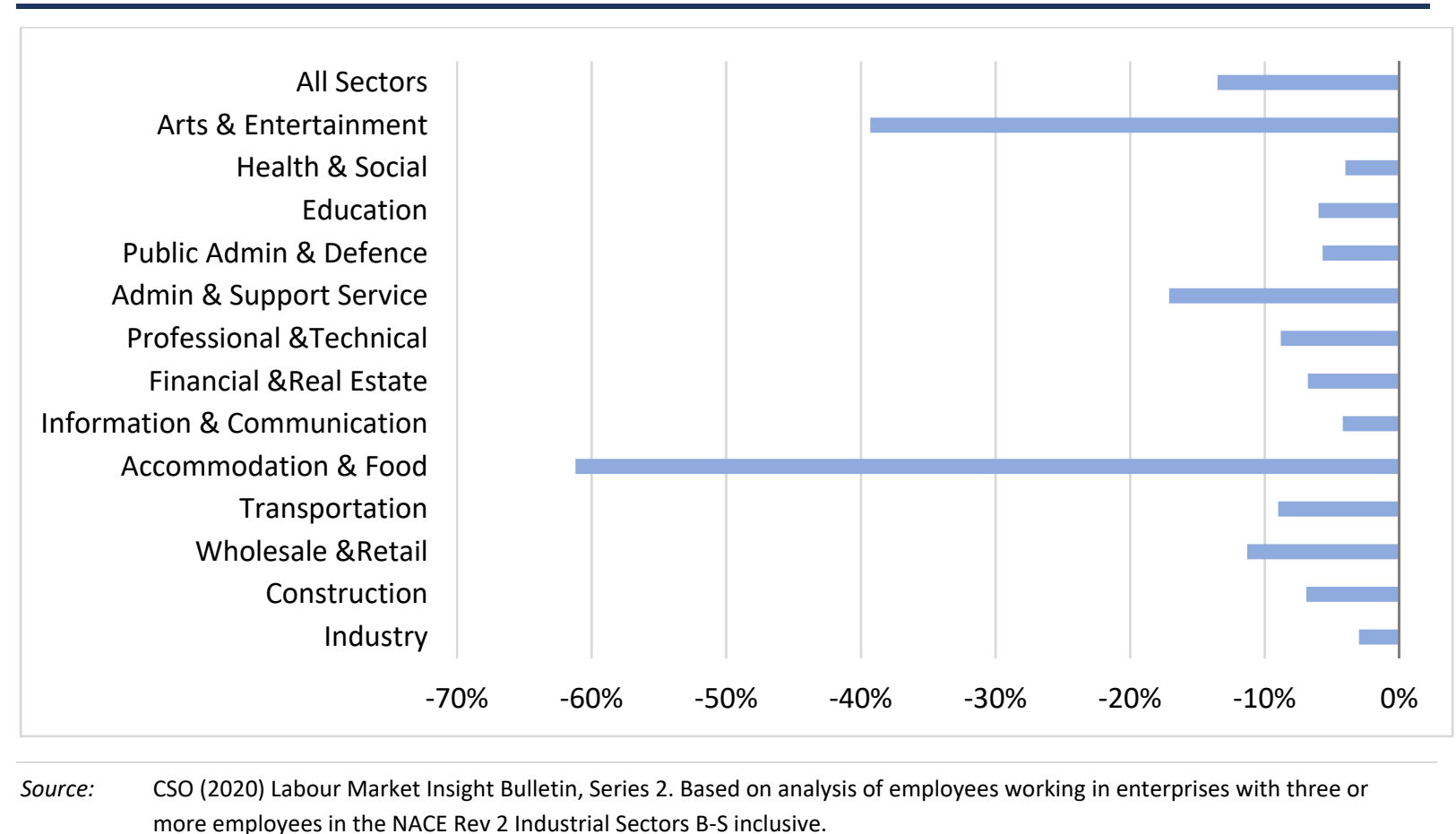
more employees in the NACE Rev 2 Industrial Sectors B-S inclusive. 
Part of the public health response to COVID was to ask employees to work from home where possible. Non-essential workers who are unable to work from home are therefore more likely to lose their jobs (Adams-Prassl et al., 2020). Redmond and McGuinness (2020b) provide evidence that pre-pandemic non-Irish nationals were less likely to work from home than Irish nationals (10.3 per cent compared to 14.6 per cent). However, given the massive shift in employer behaviour to allow employees to work from home, we cannot assume that this pattern was replicated during the pandemic. To get a sense of the risk of job loss due to the pandemic we construct a measure of 'remotability', which aims to capture workers' ability or potential to do their job from home. For the employed the LFS contains information on whether the respondent always, sometimes or never works from home. However, this information is not available for previous jobs of those who are unemployed or inactive. Therefore, we construct a measure at occupational level i.e. everyone in a particular occupation is given the same value. The measure does not take account of other factors such as size of firm or contract (see Borjas and Cassidy, 2020, for a more sophisticated measure). We classify jobs depending on the proportion of employees in each ISCO occupation that have the ability to work from home, based on patterns of remote working before the pandemic. Occupations where fewer than 20 per cent of workers work from home sometimes or always are classified as 'low', ranges between 20 per cent and 29 per cent are classified as 'medium' and ranges of 30 per cent or over are classified as high. ${ }^{47}$ The extent to which non-Irish nationals occupy jobs that can be done remotely varies across nationality groups (Figure 4.2). The EU-West* and the non-EU groups are more likely to occupy jobs that can be done from home than Irish nationals. This is in contrast to the situation in the United States, where immigrants are much less likely to work in high remotability jobs (Borjas and Cassidy, 2020). However, a much lower proportion of those in the EU-East group (13 per cent) are in occupations where there is a high level of remotability and 73 per cent are in occupations with a low level. The EU-East group are more like immigrants in the United States in this regard (ibid.). 


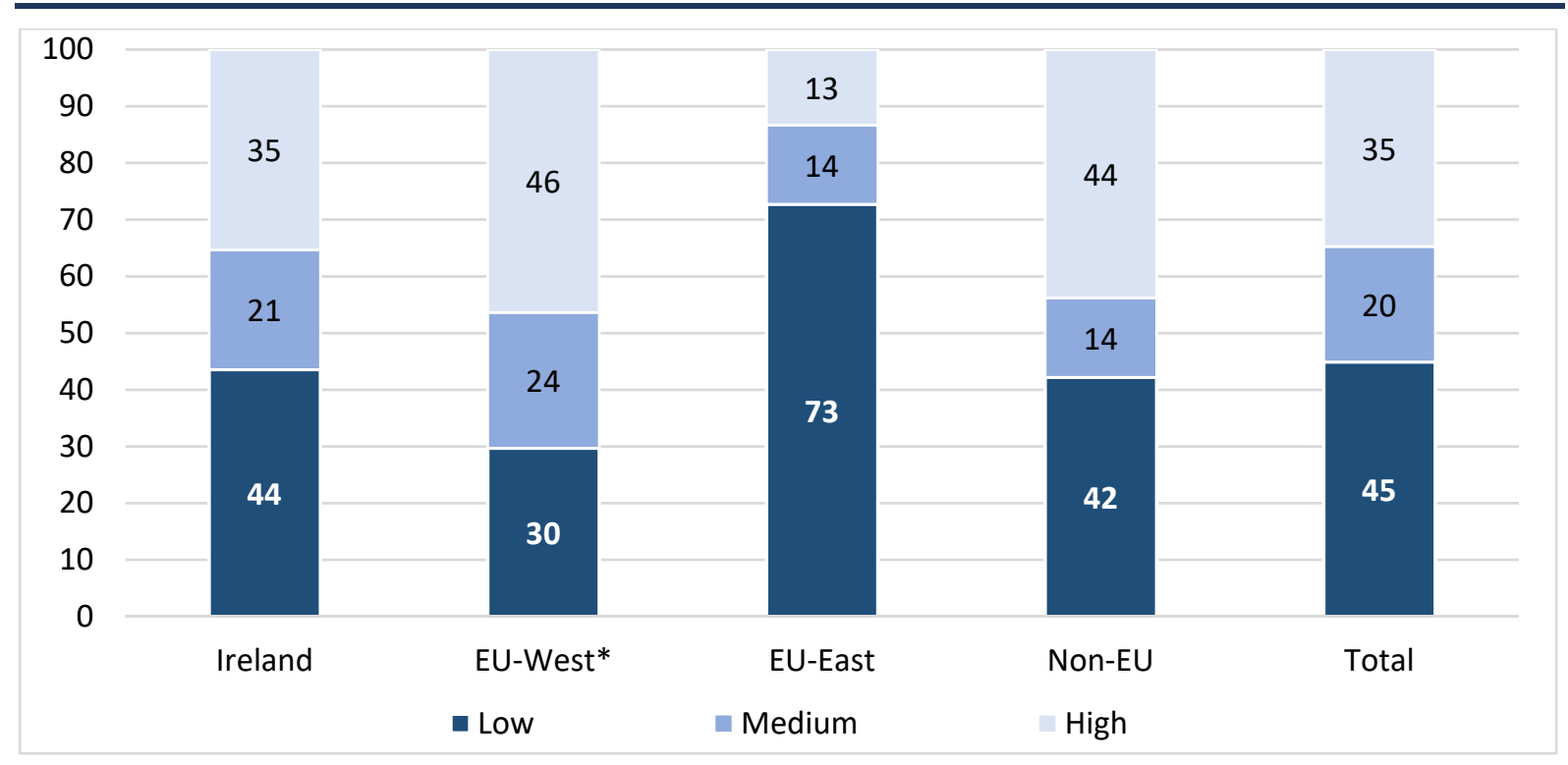

Source: $\quad$ LFS, Q1 2020 restricted to those aged 15-64 years

Note: $\quad$ Respondents at work are classified on the basis of their current occupation, those out of work by their past occupation. Therefore, respondents with no current or previous employment are excluded.

\subsection{MEASURING THE IMPACT OF COVID-19 ON EMPLOYMENT}

The measurement of unemployment during the pandemic has proved complex due to the extensive support measures put in place by the government to cushion those affected by the pandemic-related labour market shock. Many workers have been temporarily laid off but are receiving COVID-related payments (see Chapter 3 for details of eligibility). Many will have done no paid work in the week preceding the Labour Force Survey questionnaire, but will not have been actively seeking a new job if they are on temporary lay-off, which means they would not be counted as unemployed using the traditional ILO definition of unemployment (see Glossary), nor are they receiving unemployment benefit, so do not appear on the Live Register.

Due to this complexity we examine the impact of the COVID crisis on employment among non-Irish nationals in three ways. First, we present published figures on the nationality of those who are in receipt of COVID-specific payments. Secondly, we model employment in Quarter 1 (pre-pandemic) and Quarter 2 of 2020 (pandemic) and examine whether the change between those two periods is greater for nonIrish national groups than for the native Irish population. Thirdly, we analyse data from Labour Force Survey in Q2 2020 on the characteristics of those who are absent from work due to COVID. 


\subsection{RECEIPT OF PUP AND TWSS (PANDEMIC RELATED SUPPORTS)}

According to figures from the CSO (2020d) 329,991 people were availing of the PUP in the week ending 1 November down from a high of just over 600,000 in May 2020. The number of individuals availing of PUP decreased between May and September but began to rise again in late October and November due to the implementation of a second national lockdown on 21 October. Table 4.1 shows the breakdown of PUP claimants by nationality groups. The proportion of PUP recipients that are non-Irish nationals has risen marginally over the course of the pandemic, from 28 per cent in May to 29 per cent in early November. This figure is significantly higher than the proportion of non-Irish nationals in the labour force in Q1 2020 before the pandemic hit (17.5 per cent). Eastern Europeans and workers from the non-EU group accounted for the highest proportion of PUP claimants among non-Irish nationals.

TABLE 4.1 PROPORTION RECEIVING PUP PAYMENTS BY NATIONALITY GROUP

\begin{tabular}{|c|c|c|c|c|c|}
\hline & $\begin{array}{l}03 / 05 / 20 \\
03 / 05 / 20\end{array}$ & $\begin{array}{l}05 / 07 / 20 \\
05 / 07 / 20\end{array}$ & $\begin{array}{l}06 / 09 / 20 \\
27 / 09 / 20\end{array}$ & $01 / 11 / 20$ & $\begin{array}{c}\text { Labour Force } \\
\text { Q1 } 2020\end{array}$ \\
\hline & $\%$ & $\%$ & $\%$ & $\%$ & $\%$ \\
\hline Irish nationals & 72 & 71 & 70 & 71 & 82.5 \\
\hline Non-Irish nationals & 28 & 29 & 30 & 29 & 17.5 \\
\hline \multicolumn{6}{|l|}{ Of which: } \\
\hline EU-West* & 5 & 6 & 6 & 6 & 5.3 \\
\hline EU-East & 13 & 13 & 12 & 13 & 7.3 \\
\hline Non-EU & 9 & 10 & 12 & 10 & 4.9 \\
\hline $\mathbf{N}$ of Claimants & 602,107 & 412,859 & 217,142 & 329,991 & \\
\hline
\end{tabular}

Source: $\quad$ PUP figures from CSO $2020 .^{48}$ Labour Force Figures from LFS 2020, Q1.

Notes: $\quad$ EU-West* includes UK but excludes Ireland. Labour force figures restricted to those aged 15-64.

Overall, 298,878 people were availing of the Temporary Wage Subsidy Scheme in the week ending 30 August. The EWSS replaced this scheme beginning 1 September, however EWSS figures by nationality have not been released at the time of writing. According to figures from Revenue, 347,200 employees ${ }^{49}$ received EWSS payments in the month of October which is a significant increase from the figures presented in Table 4.2 for August. Similar to PUP figures, 24 per cent of those availing of TWSS in August were non-Irish nationals. Eastern European workers were found to account for the highest percentage of TWSS payments among non-Irish nationals. At the time of writing (November 2020) Ireland was in the middle of Level 5 restrictions, with non-essential retail closed, so figures for receipt of EWSS are likely to fluctuate over time with public health restrictions. 


\begin{tabular}{|l|c|c|c|c|}
\hline & $\mathbf{0 3 / 0 5 / 2 0}$ & $\mathbf{0 5 / 0 7 / 2 0}$ & $\mathbf{3 0 / 0 8 / 2 0}$ & Labour Force \\
\hline & $\%$ & $\%$ & $\%$ & $\%$ \\
\hline Irish nationals & 76 & 76 & 76 & 82.5 \\
\hline Non-Irish nationals & 24 & 24 & 24 & 17.5 \\
\hline Of Which: & & & & 5.3 \\
\hline EU-West* & 6 & 5 & 6 & 7.3 \\
\hline EU-East & 13 & 13 & 13 & 4.9 \\
\hline Non-EU & 5 & 5 & 6 & \\
\hline N of Claimants & 321,877 & 296,621 & 298,878 & \\
\hline
\end{tabular}

Source: $\quad$ TWSS figures from CSO 2020..$^{50}$ Labour force figures from LFS 2020 Q1.

Notes: $\quad$ EU-West* includes the UK but excludes Ireland; EWSS replaced the TWSS on 1 September 2020. Labour force figures restricted to those aged $15-64$.

\subsection{NATIONALITY AND JOB LOSS}

The claimant figures suggest that non-Irish nationals are over-represented among those on the pandemic income supports. In the second part of analysis we model employment as recorded in Q1 and Q2 of the 2020 Labour Force Survey. Our aims are to check for evidence of greater job loss among non-Irish groups, to assess the scale of this difference, and to explore some of the factors behind this pattern. In particular, we are interested in whether any non-Irish disadvantage can be explained by occupation and sector sorting, in that non-Irish groups are simply concentrated in sectors closely affected by the government's lockdown (such as hospitality and travel).

In this analysis we count those who have worked for pay or profit during the reference period as being employed. We do not include those temporarily absent from work, who would usually be included on an ILO definition of employment. ${ }^{51}$ The dependent variable in the model is being employed versus not employed (unemployed, inactive or temporarily absent). We use robust standard errors to take account of clustering at the individual level.

Model 1 shows that, pooling Q1 and Q2 together, those who are EU-East or non-EU nationals have significantly lower odds of employment than Irish nationals. EU-West nationals do not differ significantly from Irish nationals. The model also demonstrates the sharp drop in employment for the whole sample between Q1 and Q2, as the odds of employment more than halve.

https://www.cso.ie/en/statistics/labourmarket/liveregister/detailedCovid19incomesupportandliveregistertables. While this excludes some of those absent for non-COVID reasons, e.g. maternity leave and holidays, we expect that this proportion should not vary much between the two quarters and therefore excluding the group from both quarters will not affect the change over time. 
In Model 2 we include the interaction between Q2 and nationality, to test if the fall in employment was greater for non-Irish nationals than for Irish nationals. The interaction effects suggest that the fall in employment was greater for Eastern European nationals compared to Irish nationals. As the coefficients for interactions in logistic models are difficult to interpret, we present the results graphically based on the predicted probabilities for each group. Figure 4.3 shows that the fall in employment was sharper for Eastern European nationals, when compared to Irish nationals. The non-EU group have a significantly lower probability of employment than Irish nationals in both quarters, as has been found in previous research (e.g. McGinnity et al., 2018a; 2020a). Part of the reason for this is the high proportion of non-EU nationals who come to Ireland to study; others may not have permission to work (see McGinnity et al., 2020a). However, significant for this report is that the scale of the decline in employment has been similar for non-EU nationals and Irish nationals. EU-West nationals had high employment rates pre-pandemic, and there is no evidence here that they are disproportionately affected by the fall in employment due to the pandemic. Model 2 also includes a set of control variables that operate as expected: higher education is associated with higher employment odds ratios; lone parenthood and age are associated with reduced odds ratios of employment. These measures, although important in themselves, do little to explain national group differences in employment. This suggests that national group differences are not simply demographic compositional differences between non-Irish and Irish nationals. 


\begin{tabular}{|l|l|l|l|l|}
\hline & (1a) & (2) & (3) & (4) \\
\hline Irish Nationals & 1 & $\begin{array}{c}\text { Controlling for } \\
\text { gender, age, family } \\
\text { status \& education }\end{array}$ & $\begin{array}{c}\text { Add Remotability } \\
\text { in occupation }\end{array}$ & $\begin{array}{c}\text { Add occupation \& } \\
\text { sector }\end{array}$ \\
\hline EU-West* & 0.982 & 1 & 1 & 1 \\
\hline EU-East & $0.673^{* * *}$ & $0.740^{* *}$ & $0.718^{* *}$ & $0.747^{*}$ \\
\hline Non-EU & $0.850^{*}$ & $0.787^{*}$ & 0.907 & 0.991 \\
\hline Q1 2020 & 1 & $0.583^{* * *}$ & $0.611^{* * *}$ & $0.690^{* *}$ \\
\hline Q2 2020 & $0.456^{* * *}$ & 1 & 1 & 1 \\
\hline EU-West* Q2 & & $0.443^{* * *}$ & $0.435^{* * *}$ & $0.421^{* * *}$ \\
\hline EU-East Q2 & 1.123 & 1.119 & 1.121 \\
\hline Non-EU Q2 & & $0.632 * * *$ & $0.632^{* * *}$ & $0.614 * * *$ \\
\hline Observations & 27,895 & 1.125 & 1.104 & 1.093 \\
\hline Pseudo R-squared & 0.034 & 27,895 & & 27,895 \\
\hline chi2 & $1,091.5$ & 0.060 & 27,895 & 0.091 \\
\hline Log likelihood & $-15,341.9$ & $-14,940.7$ & $-14,757.7$ & $2,882.0$ \\
\hline
\end{tabular}

Source: $\quad$ LFS 2020 Q1 and Q2.

Note: $\quad$ Restricted to those aged 15-64 years and valid on all covariates. For those out of work previous occupation/sector is used. Those who have no previous occupation are excluded. Models are unweighted. An odds ratio of greater than 1 means the group are more likely to be employed compared to the reference category. An odds ratio less than 1 means the group are less likely to be employed compared to the reference category. For full model results, including detailed list of sector of activity and occupations used, see Appendix Table A4.1***p<0.001; **p<0.01; *p<0.05.

In Model 3 we include a control which measures the extent to which occupations allow workers to work remotely. Model 3 shows that occupations that offer medium or high levels of working from home are associated with a higher odds ratio of employment (pooling across the two quarters, not shown). Moreover, when we test the interaction between remotability and time period, we find that there is a much less drastic drop in employment between the two quarters for those in occupations where they can work from home (see Figure 4.4). While there is no difference between these three groups of occupations in Q1, occupations with low level of working from home experience a much sharper fall in employment, consistent with findings using a more detailed measure of remotability of jobs in the United States (Borjas and Cassidy, 2020). Controlling for the remotability of occupations does not alter the interaction between EU-East and Q2. This suggests that the greater exposure of Eastern European nationals to COVID-related job loss is not explained by their location in jobs that are less amenable to working from home. It is also of note that, as shown in Figure 4.2, for those who are at work, EU-West nationals (including UK nationals) and non-EU nationals are actually more likely to work in jobs that can be done from home than Irish nationals. 
0.9

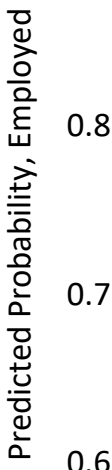

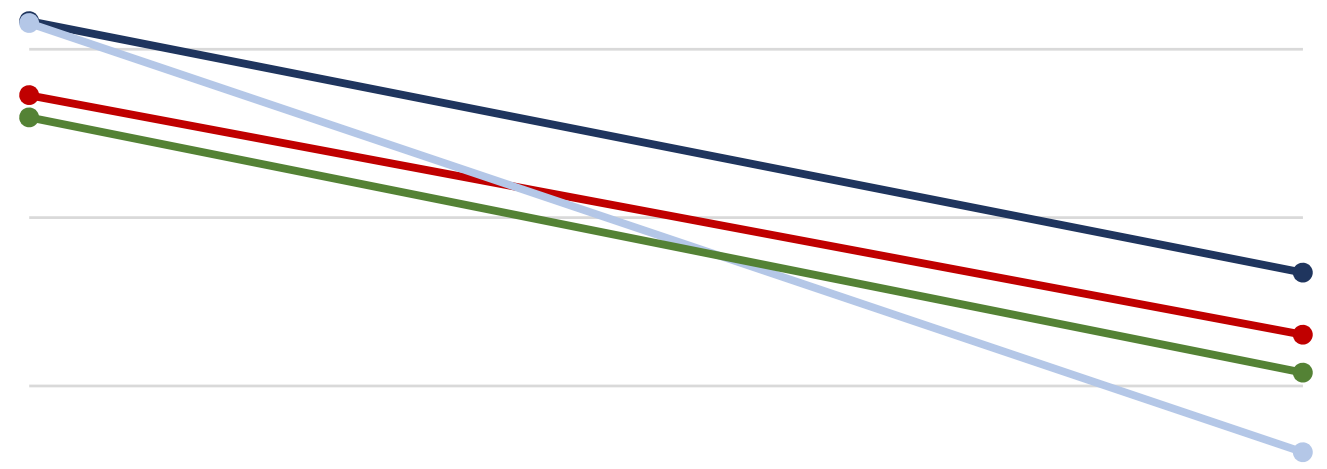

0.5

Q1 2020

$\longrightarrow$ Ireland $\longrightarrow$ EU-West* $\rightarrow$ EU-East $\rightarrow$ Non-Eu

Source: LFS Q1 and Q2. Probabilities derived from Model 4 in Table 4.1, which controls for gender, age, family status and education. EU-West includes the UK in this chart but excludes Ireland.

FIGURE 4.4 PREDICTED PROBABILITY OF EMPLOYMENT IN Q1 AND Q2 2020 BY LEVEL OF HOMEWORKING IN OCCUPATION

0.9

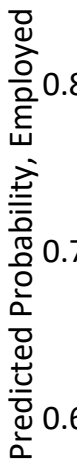

0.5

Q1 2020

Survey Quarter

$\rightarrow$ Low $\quad-$ Medium

Source: LFS Q1 and Q2. Probabilities derived from Model 3 in Table 4.1 which controls for gender, age, family status and education. 
Model 4 includes controls for detailed occupation and sector categories instead of the working from home classification (see Appendix Table A4.1); while these two factors have a strong association with employment, their inclusion in the model does not affect the interaction between EU-East and Q2 signalling greater job loss for East European nationals. It is possible that occupational segregation within occupations and sectors plays a role in accounting for greater job loss among Eastern Europe nationals i.e. a more detailed occupational breakdown might reduce the EU-East* Q2 interaction. Geographical location may also interact with sector; we know that migrants are more residentially concentrated within cities (Fahey et al., 2019) and larger cities may be more prone to COVID-related unemployment in the service sector.

In additional models we examine whether the decline in employment has been more acute for some groups of non-Irish workers, for example young people and men/women compared to Irish nationals with the same characteristics. To do this we run separate models for men and women, younger and older workers and again run the interaction between migrant status and Q2. The graphs in Figure 4.5 show that for both men and women the decline in employment was similar for Irish nationals, EU-West and non-EU nationals, but that the fall in employment was sharper for EU-East Nationals. The drop was particularly sharp for women from EU-East countries (see Appendix Table A4 for full models).

We undertake a similar analysis for younger workers (aged under 30 ) and older workers (30 years and over). Figure 4.6 shows that among the younger cohort, although the EU-West start from a lower level of employment, the decline in employment is rather similar for all four groups (and the interaction is not significant). Among workers aged over 30, we see that the decline in employment is greater for EU-East nationals compared to Irish nationals. For the other groups the slopes are parallel. 
FIGURE 4.5 PREDICTED PROBABILITY OF EMPLOYMENT IN Q1 AND Q2 2020 BY NATIONALITY FOR MEN AND WOMEN

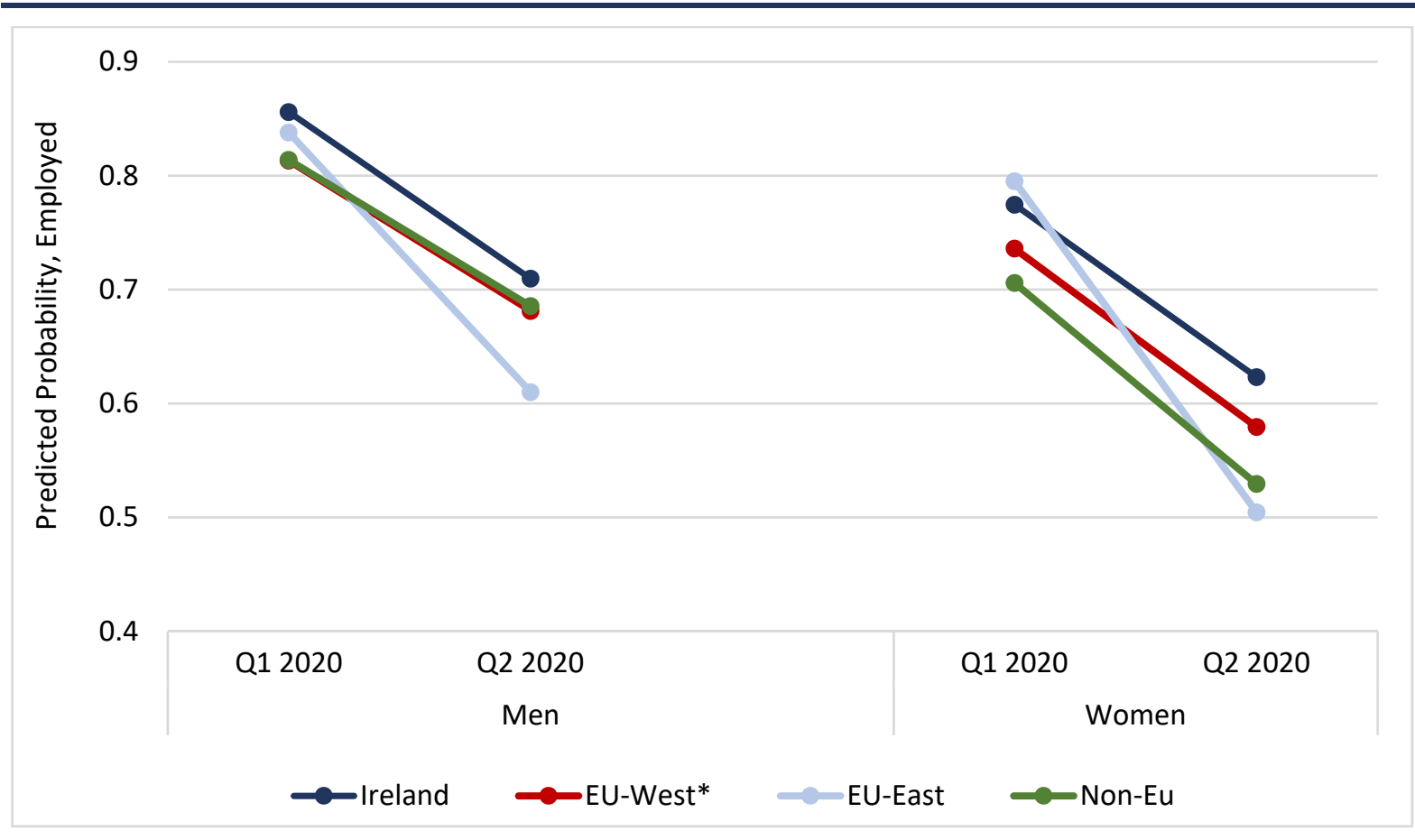

Source: LFS 2020 Q1 and Q2.

Notes: Predicted margins based on Model 2 and Model 4 in Appendix Table A4.2, controlling for age, education, family status, occupation and sector. EU-West includes the UK but excludes Ireland in these charts.

FIGURE 4.6 PREDICTED PROBABILITY OF EMPLOYMENT IN Q1 AND Q2 2020 BY NATIONALITY FOR YOUNGER (UNDER 30) AND OLDER (30 AND OLDER) AGE GROUPS

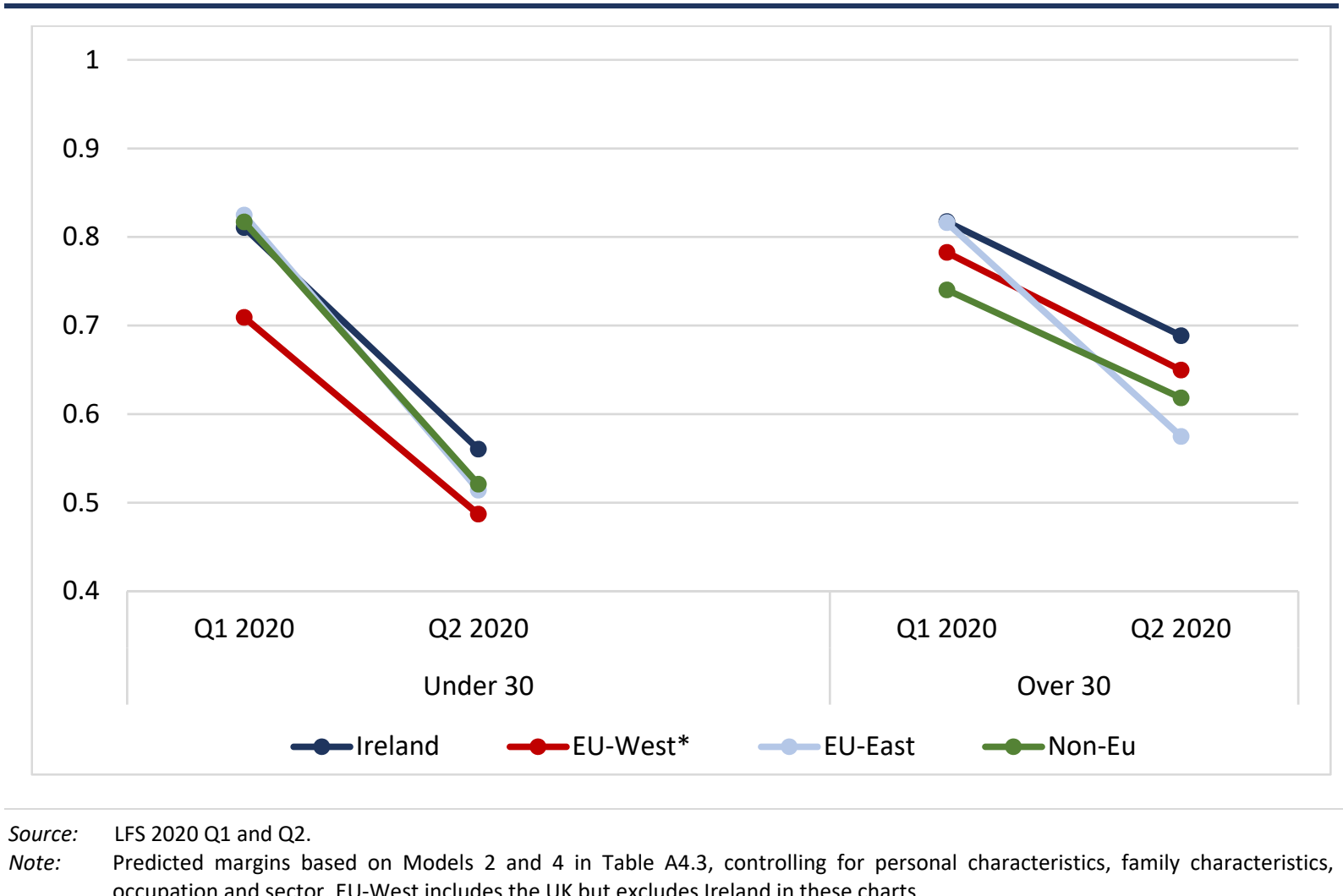
occupation and sector. EU-West includes the UK but excludes Ireland in these charts. 


\subsection{NATIONALITY AND COVID-RELATED ABSENCE}

An alternative way of assessing the impact of the pandemic on employment is to examine the characteristics of those in Q2 2020 who said that they were not in paid work during the reference week, had a job or business that they were away from and expected to go back to and the reason they were not at work was related to COVID..$^{52}$ This measure will exclude workers who lost their job due to COVID where the business closed permanently or those who did not expect to be taken back by their former employer. It is also likely to pick up those taking paid or unpaid leave to deal with childcare or other demands caused by the pandemic.

We estimate a multinomial model for this analysis. The model contrasts those who were absent due to COVID to those employed and at work. It also contrasts those out of work for other reasons (inactive and unemployed) to those at work. The results for this second set of contrasts are included in the appendix (Table A4.2), as we are primarily focused on COVID-related absence as a way of assessing the labour market impact of the pandemic.

Model 1 again shows that EU-East nationals are at a disadvantage. They have significantly higher relative risk ratios of COVID-related absence compared to Irish nationals holding age and gender constant. When we control for family status and education, non-EU nationals are also found to have higher risks of COVID absence (see Model 2). ${ }^{53}$

A small part of the EU-East effect is due to the lower 'remotability' of the jobs occupied by this group of non-Irish (see Model 3); however the relative risk for non-EU nationals remains unchanged and the EU-West* group are shown to have a higher relative risk of COVID-related absence given their positive profile in terms of the remotability of their jobs (see Figure 4.2). As expected, those in occupations with medium or high levels of remotability are less likely to experience COVIDrelated absence. In the final Model (4), we add controls for occupation and job sector. Differences in occupation and sectoral location can fully account for the greater relative risk of non-EU nationals however the EU-East group still experience an additional disadvantage. This is consistent with the findings for the model of change in employment between Q1 and Q2. business reduced in size; business closed; unable to work due to childcare reasons; and unable to work due to other personal reasons.

53 This may be due to the fact that this group are highly educated. Accounting for this, we find a somewhat higher risk of COVIDrelated absence. 
TABLE 4.4 MULTINOMIAL MODEL OF FACTORS ASSOCIATED WITH COVID-RELATED ABSENCE (Q2)

\begin{tabular}{|c|c|c|c|c|}
\hline & \multicolumn{4}{|c|}{$\begin{array}{l}\text { Risk of COVID-related absence } \\
\text { (temporary lay-off) v At Work }\end{array}$} \\
\hline & (1) & (2) & (3) & (4) \\
\hline & RRR & RRR & RRR & RRR \\
\hline Irish nationals & 1 & 1 & 1 & 1 \\
\hline EU-West* & 0.905 & 1.282 & $1.377^{*}$ & 1.280 \\
\hline EU-East & $1.846 * * *$ & $2.099 * * *$ & $1.724 * * *$ & $1.461^{* *}$ \\
\hline Non-EU & 0.988 & $1.562 * *$ & $1.517^{* *}$ & 1.167 \\
\hline Female & 1 & 1 & 1 & 1 \\
\hline Male & $0.887^{* *}$ & $0.767 * * *$ & $0.709 * * *$ & $0.692 * * *$ \\
\hline Age & $0.989 * * *$ & 1.004 & $1.008 * *$ & $1.013^{* * *}$ \\
\hline Single & & 1 & 1 & 1 \\
\hline Married & & 0.957 & 0.965 & 1.002 \\
\hline Sep/Divorced & & 1.013 & 0.989 & 0.983 \\
\hline Couple no children & & 1 & 1 & 1 \\
\hline Couple with children & & 1.074 & 1.083 & 1.111 \\
\hline Lone parent & & $1.345^{*}$ & $1.297^{*}$ & $1.311 *$ \\
\hline Living with parents & & $2.171^{* * *}$ & $2.103^{* * *}$ & $2.144^{* * *}$ \\
\hline Other HHs & & 1.098 & 1.095 & 1.152 \\
\hline Does not hold tertiary degree & & 1 & 1 & 1 \\
\hline Holds tertiary degree & & $0.350 * * *$ & $0.534 * * *$ & $0.621 * * *$ \\
\hline Low levels remotability & & & 1 & \\
\hline Medium levels & & & $0.429 * * *$ & \\
\hline High levels & & & $0.358 * * *$ & \\
\hline Occupation (ref: Managers) & & & & 1 \\
\hline Professionals & & & & $0.709^{* *}$ \\
\hline Technicians & & & & 0.966 \\
\hline Clerical support & & & & 0.858 \\
\hline Services \& sales & & & & $1.821 * * *$ \\
\hline Skilled agricultural & & & & $0.544^{*}$ \\
\hline Craft \& related & & & & $2.534 * * *$ \\
\hline Plant \& machinery & & & & $2.315^{* * *}$ \\
\hline Elementary occupations & & & & $1.564^{* * *}$ \\
\hline C Manufacturing & & & & 1 \\
\hline A-B Agriculture, mining \& quarrying & & & & $0.465^{* *}$ \\
\hline D-E Utilities & & & & 0.513 \\
\hline F Construction & & & & $4.018^{* * *}$ \\
\hline G-H Wholesale retail transportation & & & & $1.992 * * *$ \\
\hline I Accommodation \& food & & & & $16.00^{* * *}$ \\
\hline J-K-L Information, financial services \& real estate & & & & 0.778 \\
\hline M-N Professional scientific technical \& admin & & & & $2.545^{* * *}$ \\
\hline O-P-Q Public admin, education \& health & & & & $1.715^{* * *}$ \\
\hline Observations & 12,735 & 12,735 & 12,735 & 12,735 \\
\hline Pseudo R-squared & 0.011 & 0.055 & 0.072 & 0.124 \\
\hline chi2 & 236.6 & $1,128.8$ & $1,486.2$ & $2,556.8$ \\
\hline Log likelihood & $-10,210.1$ & $-9,764.0$ & $-9,585.3$ & $-9,050.1$ \\
\hline
\end{tabular}

Source: LFS 2020 Q2.

Note: $\quad$ Restricted to those aged 15-64 years and valid on all covariates. For those out of work previous occupation/sector is used. Those who have no previous occupation are excluded. Models are unweighted. An odds ratio of greater than 1 means the group are more likely to be on COVID-related absence compared to the reference category. An odds ratio less than 1 means the group is less likely to be on COVID-related absence. ${ }^{* * *} p<0.001 ;{ }^{*} p<0.01 ;{ }^{*} p<0.05$. 
A test of the interaction between nationality and gender again shows women are more vulnerable to COVID-related disruptions. The pattern of results is similar for men and women in terms of the ordering of non-Irish groups; however only for women is the gap between EU-East and Irish nationals significant after controlling for occupation and sector (Figure 4.7). There is no significant interaction between national group and age i.e. the distribution of COVID absence by age is the same for the three non-Irish groups and Irish nationals. However, we do find a significant interaction by education status; graduates from EU-East countries fare worse than Irish graduates (see Figure 4.8).

FIGURE 4.7 PREDICTED PROBABILITY OF COVID-RELATED ABSENCE VERSUS EMPLOYMENT FOR MEN AND WOMEN, Q2 2020

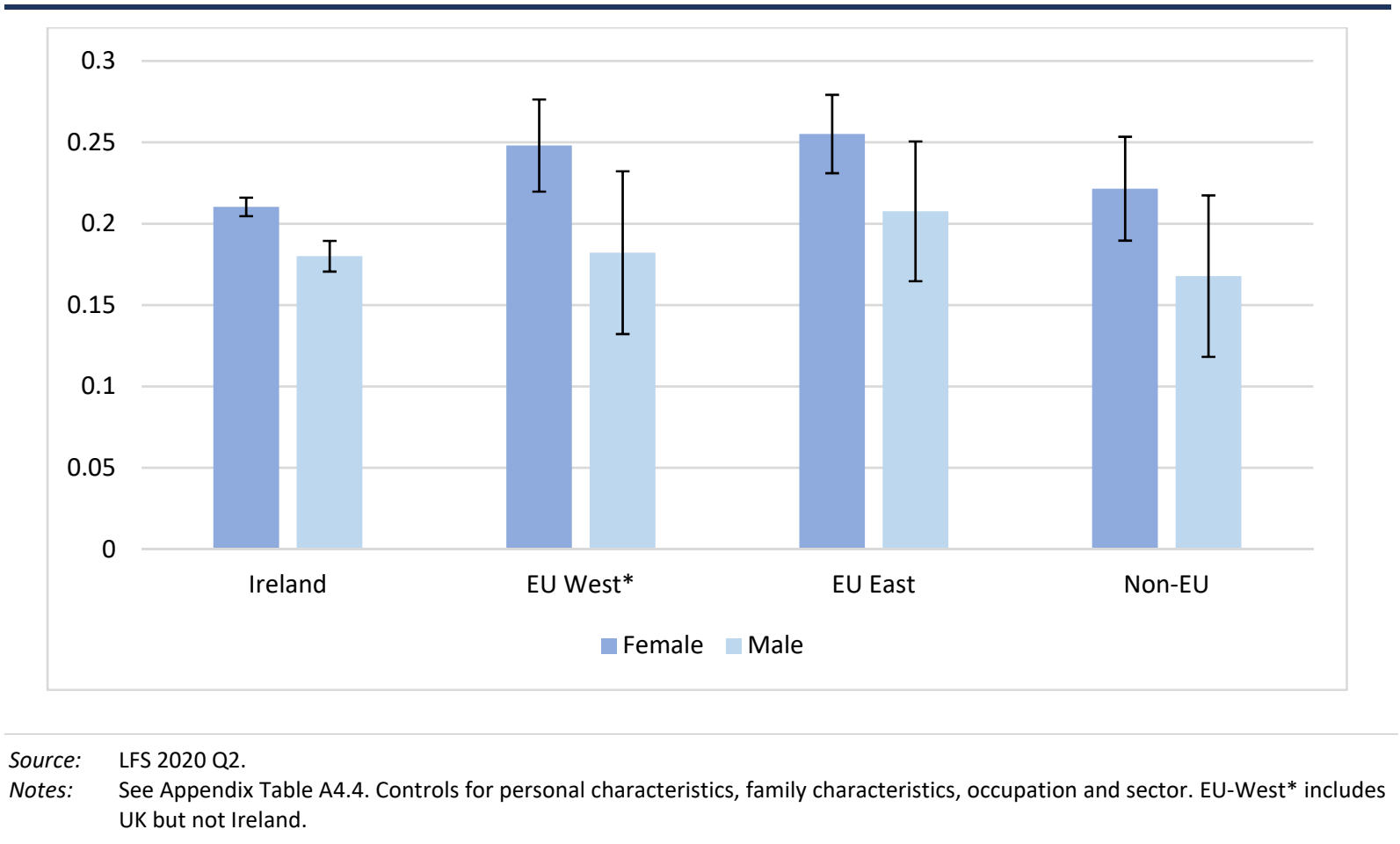


FIGURE 4.8 PREDICTED PROBABILITY OF COVID-RELATED ABSENCE VERSUS EMPLOYMENT FOR GRADUATES AND NON-GRADUATES BY NATIONALITY

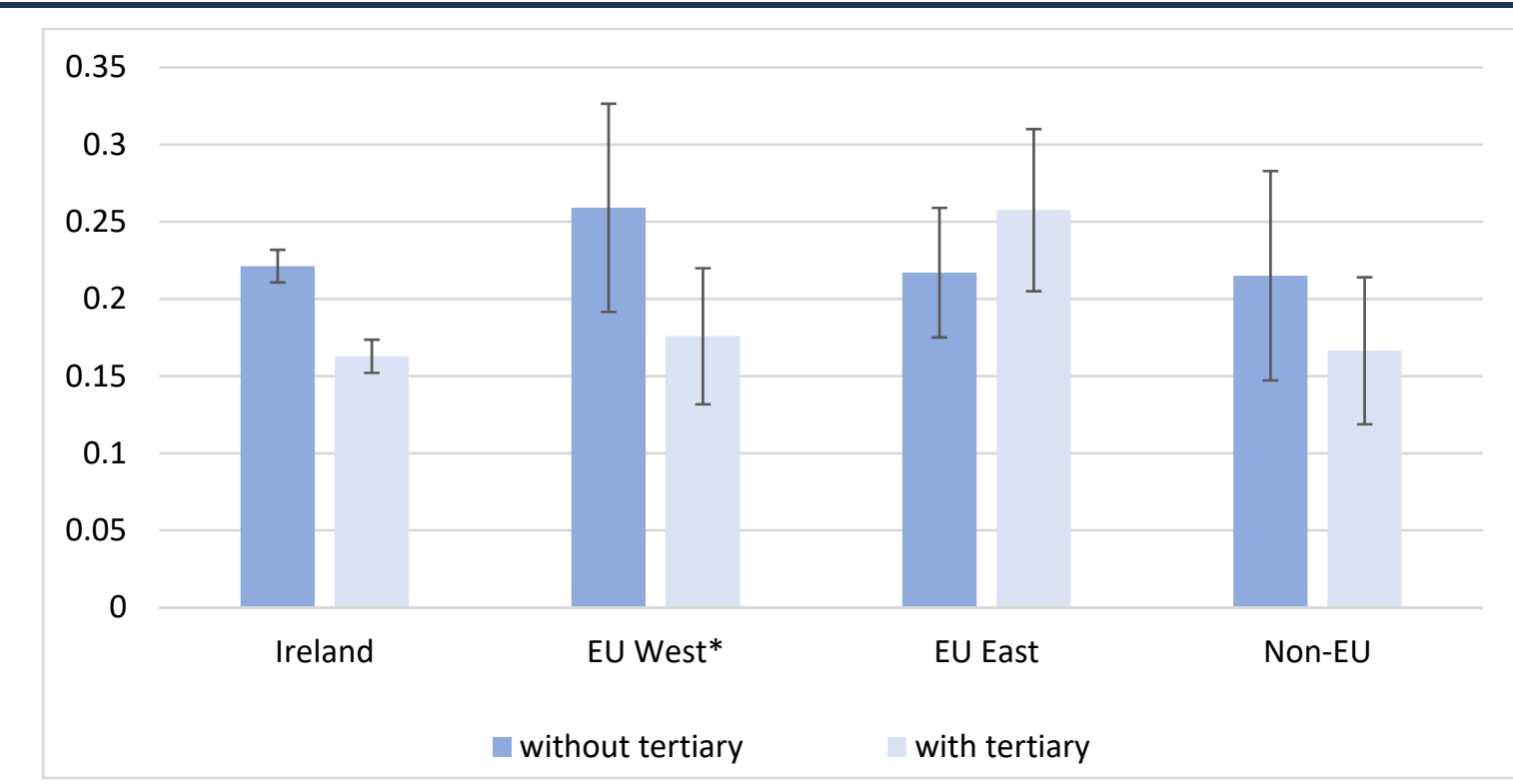

Source: $\quad$ LFS 2020 Q2.

Notes: $\quad$ See Appendix Table A4.5. Controls for personal characteristics, family characteristics, occupation and sector. EU-West* includes UK but not Ireland.

\subsection{SUMMARY}

In this chapter we explored the exposure of non-Irish nationals to COVID-related unemployment using three measures. The analysis reveals that non-Irish nationals from different regions of origin have divergent experiences. On all three measures Eastern European nationals were more exposed to COVID-related impacts. They were over-represented on PUP and TWSS payments, they experienced a more severe drop in employment between Q1 and Q2 of 2020 and they were more likely to be out of work due to COVID in Q2 than Irish nationals. Their employment rates were very high prior to the pandemic, but their employment has been disproportionately affected by it. The fall in employment was particularly sharp for EU-East women. Similarly, while in general younger workers have been most affected overall, EU-East nationals aged 30 years and over have been harder hit than Irish nationals in the same age group in terms of employment decline. For COVID-related absence EU-East graduates were disproportionately impacted.

The non-EU group are somewhat over-represented on some of the measures used in this chapter, for example receipt of the Pandemic Unemployment Payment (PUP), though not on the other COVID-related payment (TWSS). They are also somewhat more likely to be on COVID-related absence/unemployment, though only after accounting for their educational qualifications and other demographic characteristics. The non-EU group contains a diverse set of people, including those from anglophone countries like Australia, the US and India, alongside those from Africa who experienced higher levels of labour market disadvantage prior to the 
pandemic (see McGinnity et al., 2020a), so it is likely that group experiences differ within the non-EU group. The employment rates of non-EU nationals were lower than those of Irish nationals prior to the pandemic for a number of reasons, mainly linked to their residence permissions (see McGinnity et al., 2020a for a discussion), but their overall employment rates have not been disproportionately affected by the pandemic.

Concentration in occupations that have been more adversely affected by the pandemic, especially the accommodation and food sector, accounts for some of these differences, and in the case of the EU-East group, over-representation in occupations with low levels of remote working. However, the EU-East group appear more adversely affected even when occupation and sector are considered. This may reflect additional segregation of non-Irish nationals within occupations and sectors that is not picked up in the broad categories included in our analyses.

Non-Irish nationals from West European countries, including the UK, have not experienced a disproportionate drop in their employment due to COVID-19, and are not more likely to be in receipt of COVID-related payments.

It is unclear as yet what the longer-term consequences of this employment shock will be for non-Irish nationals in the Irish labour market. At present, it is not clear how many of those currently receiving COVID-related payments will actually have a job to return to or will move from 'temporary layoff' to unemployment. It does seem likely that those in receipt of these payments are in a much less secure labour market position than those who have not been temporarily laid off, and that the longer the lockdown continues, the more insecure those jobs will become. 



\section{Non-Irish nationals as key workers}

Key workers throughout the crisis worked in many different occupations and sectors. Although the pandemic has affected the livelihoods of both nationals and non-nationals, previous research from the UK, US and EU on the effects of the COVID crisis has shown that migrants have been disproportionately affected by the pandemic with migrants overrepresented both in front-line occupations (Gelatt, 2020; Fassani and Mazza, 2020; Fernández-Reino and McNeil, 2020), and in occupations hardest hit by closures due to COVID such as retail and hospitality (Gelatt, 2020; Fernández-Reino and McNeil, 2020). Key workers are not only essential for the country's COVID response but may also be more vulnerable to the virus if they have face-to-face contact with a large number of customers, patients or co-workers in close proximity. This is particularly true for those working in health professions, whose infection risk is much higher than other professions, but also those working in essential retail.

The definition of a key worker differs by country due to differences in the types and severity of restrictions implemented throughout the pandemic. In addition, definitions may differ in cross-national research on the topic, depending on the categories and information available on national labour market data. Typical labour force definitions such as sector of activity and occupation were not designed for the purpose of defining key workers. This chapter compares Irish and non-Irish nationals to be consistent with the Integration Monitor 2020, but note that many international studies focus on migrants, typically defined as those born outside their country of residence. In this paper we expand on the definition of essential employees in Ireland used by Redmond and McGuinness (2020a) ${ }^{54}$ in the early stages of the pandemic, to include employees deemed essential in the more recent pandemic period (specifically following the essential services list under Level 5 restrictions published in October 2020). ${ }^{55}$ Using this definition there are 12 broad categories of key workers: health professionals, health associate professionals, other health employees, armed forces, defence and public administration, retail sales, transport operatives, education workers, agricultural employees, workers in utilities (such as electricity, gas) and waste management, those working in the manufacturing of specific products (see Appendix Table A1.1. for examples of 
professions and operational definitions). ${ }^{56}$ In this section we consider the proportion of Irish and non-Irish nationals who are key workers in any sector, and then focus on keyworkers in a number of specific sectors in which they are employed. Data are based on all waves of the Labour Force Survey from Q1 2017 to Q4 2019 in order to generate enough cases to produce meaningful tables. ${ }^{57}$ Note that it is difficult to measure the concept of a 'key worker' with complete accuracy using the Labour Force Survey, not least because the definition of which workers or services counted as essential by the government has evolved throughout the pandemic.

Figure 5.1 shows that overall, Irish nationals are significantly more likely to be defined as 'key workers' (47 per cent) compared to non-Irish nationals (37 per cent). While a lower proportion of all non-Irish workers are classified as key workers, rates of key work vary within the non-Irish group. A lower proportion of workers from Western Europe (30 per cent) and Rest of the World (29 per cent) are classified as key workers compared to Irish nationals and all other non-Irish national groups. African and Asian workers (42 per cent of each group) are the most likely to be key workers among non-Irish nationals.

FIGURE 5.1 PROPORTION OF IRISH AND NON-IRISH NATIONALS CLASSIFIED AS KEY WORKERS (LFS 2017-2019)

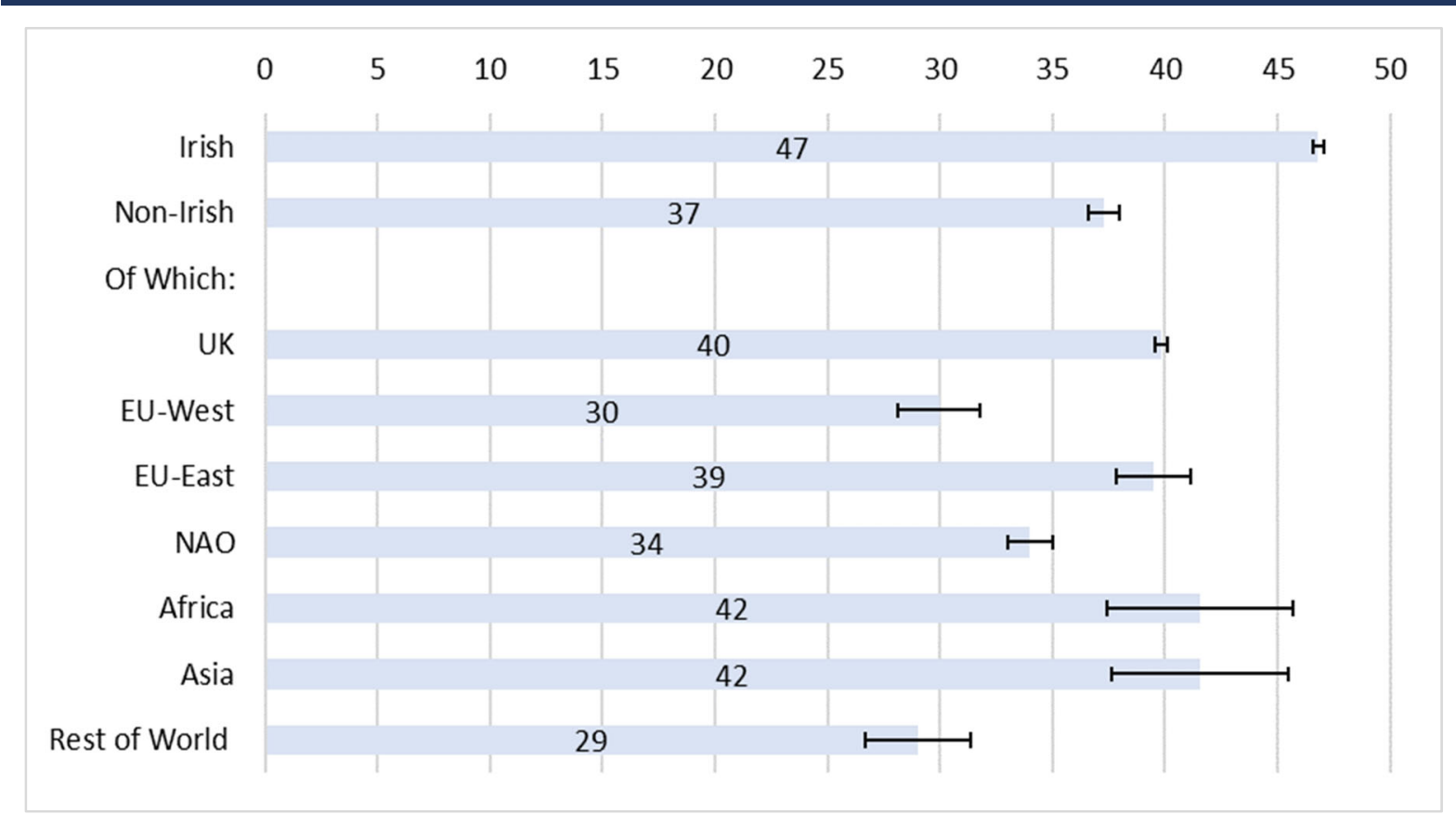

Source: $\quad$ Authors' calculations. Labour Force Survey (Q1-Q4, 2017-2019).

With thanks to our ESRI colleague Paul Redmond for sharing his programme to code the LFS data which we then expanded using the later Level 5 definition of essential services published in October 2020.

57 In a similar way to Redmond and McGuinness (2020a), the data are pooled to generate enough cases and what is reported is the average across the years. 
The high concentration of certain nationality groups as key workers differs by sector and across countries. In the UK the proportion of migrant workers is highest among the health, food preparation and transport sectors. In the US the highest proportions of migrant workers worked in transportation, agriculture and manufacturing sectors. Figures 5.2, 5.3 and 5.4 present the proportion of key workers among nationality groups in key sectors that include a large number of key workers - the healthcare sector, essential manufacturing and education.

In Figure 5.2 we examine the proportion of Irish and non-Irish nationals in health and related sectors. Healthcare and related sectors contain one of the most at-risk labour forces for contracting COVID due to the nature of their work which involves close proximity to, and treatment of, those with the COVID virus. This is reflected in the number of cases linked to COVID outbreaks among healthcare workers. As of 27 November, 17 per cent of the cumulative confirmed cases linked to COVID-19 outbreaks were among healthcare workers. Cases among healthcare workers have been consistently high throughout the pandemic rising to a high of 35 per cent of cases linked to outbreaks by 17 April (CSO, 2020c). According to figures from the CSO using CIDR figures matched to census data, those who worked in the health and social care sector accounted for 22 per cent of COVID cases despite making up 11 per cent of employees in April 2016 (CSO, 2020a).

FIGURE 5.2 PROPORTION OF IRISH AND NON-IRISH NATIONALS CLASSIFIED AS KEY WORKERS IN HEALTH AND RELATED SECTORS (LFS 2017-2019)

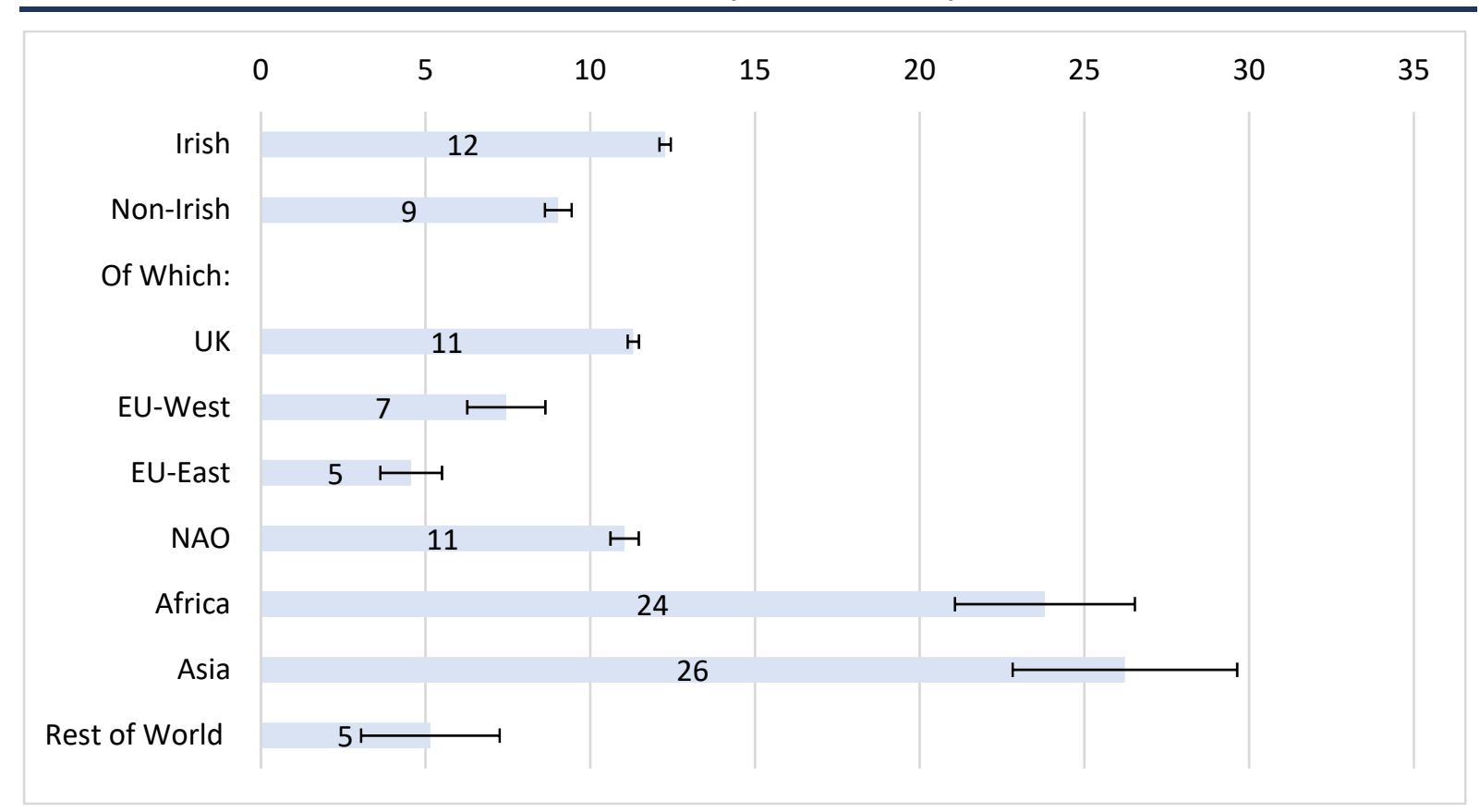

Source: $\quad$ Authors' calculations. Labour Force Survey (Q1-Q4, 2017-2019). 
Figure 5.2 shows that 12 per cent of Irish nationals are key workers in the health sector, compared to 9 per cent of non-Irish nationals. However, employment in this sector differed significantly across groups. Whilst those from the UK (11 per cent) and North America, Australia and Oceania (11 per cent) have a similar share working in health and related sectors compared to Irish nationals, Eastern European nationals ( 5 per cent) and the Rest of the World group ( 5 per cent) have significantly lower levels of key employment in this sector. Notably, African (24 per cent) and Asian (26 per cent) nationals have significantly higher rates of employment as key workers in health and related sectors compared to Irish nationals and all other national groups. The results for African and Asian nationals reflect findings from the UK which show that non-EU migrants are more likely to work as health professionals compared to migrants from within the European Union (Fernández-Reino and McNeil, 2020). The high levels of participation among Asian nationals may potentially explain the high rates of COVID cases seen among Asian or Asian Irish ethnic groups compared to White Irish seen in Chapter 2 (see Table 2.1), as there is overlap between Asian nationality and those who define themselves as ethnic Asians. Most African nationals are Black, so their high rates of key work in the healthcare sector may also partly explain the higher rates of contracting COVID-19 among the Black ethnic group (see Table 2.1)..$^{58}$

Figure 3.3 examines the proportion of Irish and non-Irish nationals employed as key workers in the manufacturing sector. Overall non-Irish nationals (11 per cent) are significantly more likely to work in the manufacturing sector compared to Irishnationals (9 per cent), although differences in proportions are slight. Whilst workers from the UK (9 per cent), Western Europe (10 per cent) and the Rest of the World (10 per cent) group have similar levels of employment in this sector compared to Irish nationals, those from Eastern Europe (15 per cent) are significantly more likely to be key workers in the manufacturing sector compared to Irish nationals and all other non-Irish national groups. Notably Asian (6 per cent) nationals are significantly less likely to work in this sector than all other groups. These findings differ from those found in the EU which showed that migrants from outside the EU are more likely to work in manufacturing occupations than those from within the EU (Fassani and Mazza, 2020). 
FIGURE 5.3 PROPORTION OF IRISH AND NON-IRISH NATIONALS CLASSIFIED AS KEY WORKERS IN ESSENTIAL MANUFACTURING* (LFS 2017-2019)

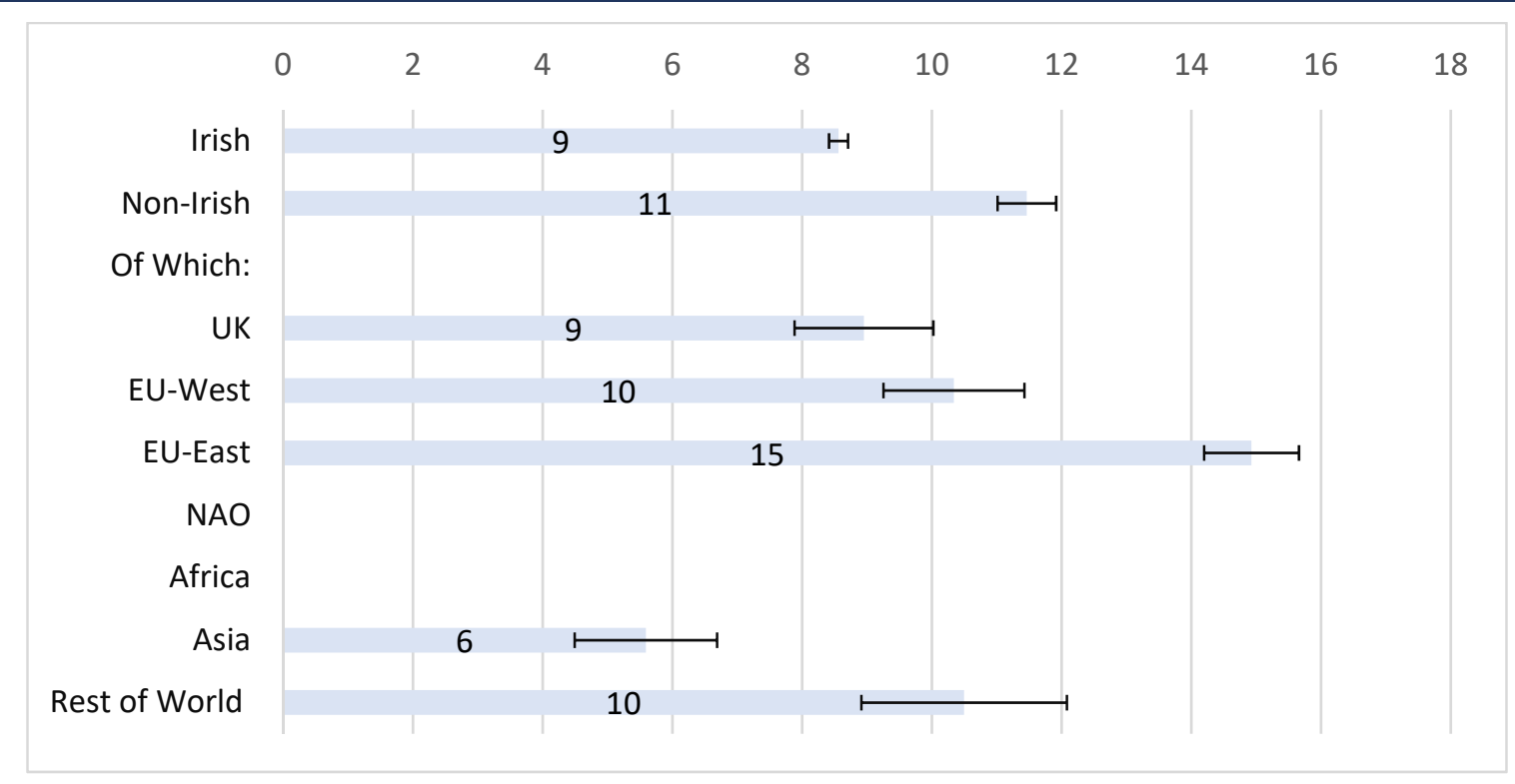

Source: $\quad$ Authors' calculations. Labour Force Survey (Q1-Q4, 2017-2019).

Notes: Includes all employees aged 15 or over. Figure lists proportions and 95 per cent confidence intervals by group. Data for North America, Australia and Oceania (NAO) and Africa are unavailable due to small cell sizes. *Essential manufacturing as defined under Level 5 restrictions, such as food, pharmaceuticals and electronics. See Appendix A1.1 for further details.

In Figure 5.4 we examine the proportion of Irish and non-Irish nationals employed as key workers in the education sector. Overall, Irish nationals (10 per cent) are significantly more likely to work in this sector compared to non-Irish nationals (4 per cent) although rates of employment vary significantly among non-Irish national groups. Workers from Eastern Europe (1 per cent), Asia ( 3 per cent) and the Rest of the World group ( 3 per cent) are significantly less likely to work in the education sector compared to Irish nationals. Although UK (7 per cent) and Western European (6 per cent) nationals are still less likely to work in this sector compared to Irish nationals, the proportions of these workers employed in this sector is significantly higher than all other non-Irish national groups. These findings are consistent with census figures from 2016 which show that only 5 per cent of those working in teaching and educational professions in Ireland were non-Irish nationals. ${ }^{59}$ 
FIGURE 5.4 PROPORTION OF IRISH AND NON-IRISH NATIONALS CLASSIFIED AS KEY WORKERS IN EDUCATION SECTOR (LFS 2017-2019)

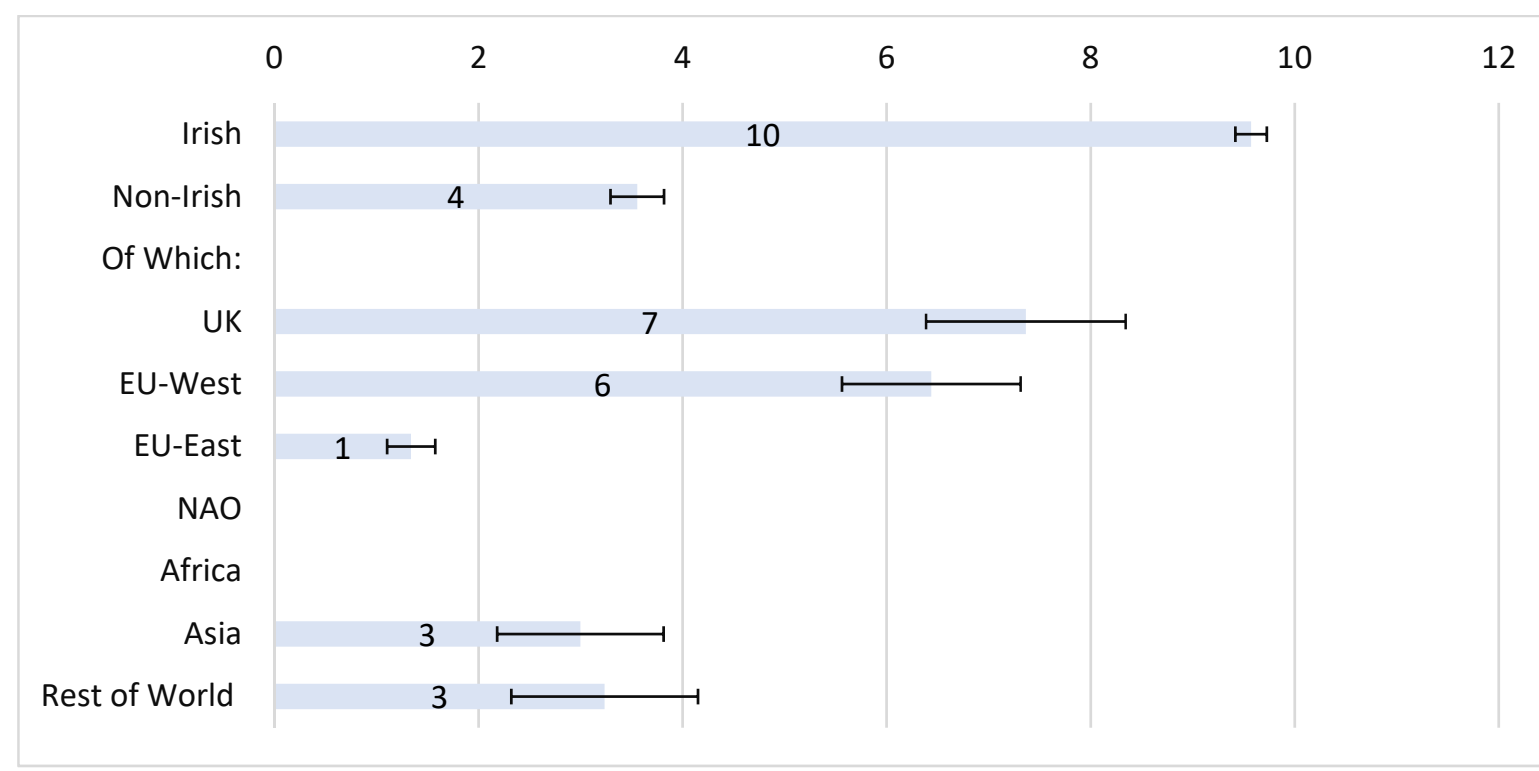

Source: $\quad$ Authors' calculations. Labour Force Survey (Q1-Q4, 2017-2019).

Notes: Includes all employees aged 15 or over. Figure lists proportions and 95 per cent confidence intervals by group. Data for North America, Australia and Oceania (NAO) and Africa are unavailable due to small cell sizes.

Fassani and Mazza (2020) find that among migrant key workers in Europe, many are overrepresented in lower-skilled occupations such as cleaning and caring. This may also be the case in Ireland, though such detailed distinctions are not possible here. The definition of key workers is evolving as government restrictions change. For example, in the early stages of the pandemic, when the definition of essential workers was published by the government, schools and childcare settings remained closed. At the time of writing, these were all open. This serves to illustrate how any definition of key workers may be subject to change throughout the pandemic and thus the demographics of the group as different sectors employ different proportions of non-Irish nationals. What this analysis does tell us is that, using this definition based on Level 5 restrictions, while non-Irish nationals are not overrepresented among key workers in Ireland overall, African and Asian nationals are particularly overrepresented among key workers working in the health sector, EU-East Europeans overrepresented among key workers in essential manufacturing, and non-Irish nationals are underrepresented among key workers in the education sector. 


\section{CHAPTER 6}

\section{Conclusion}

At the time of writing (November 2020), Ireland was in the midst of a global pandemic and associated restrictions on economic and social activity. The public health measures introduced suddenly divided jobs in the Irish labour market and the people who work in them on a number of dimensions previously unheard of. Some jobs have been defined as 'essential' - though precisely which jobs these are depends on the nature of restrictions at any given time. The 'remotability' of jobs has also emerged as a key cleavage. At various stages of the pandemic response those who can work from home have been encouraged or instructed to do so, and unprecedented numbers have been working from home. Other workers whose jobs could not be done from home but are not essential were put on temporary lay-off, supported by the State on COVID-related payments.

The purpose of this short report is to assess evidence, at this early stage, of whether the impact of the COVID pandemic so far has disproportionately affected non-Irish nationals compared to Irish nationals in terms of their vulnerability to the virus and their labour market outcomes. This report thus complements the Integration Monitor 2020, providing an early indication of the disruption of the patterns of migrant integration in Ireland immediately prior to the pandemic.

Chapter 2 considers, using albeit limited available evidence, vulnerability to the virus itself, using specially compiled statistics by the CSO. In this analysis we look at ethnicity as well as nationality, as evidence from other countries suggests this is an important dimension to consider. In terms of cases, there are marked differences across ethnic groups. Those of Black/Black Irish, those of Asian/Asian Irish ethnicity and Irish Travellers are overrepresented in COVID-19 cases, relative to their share of the population. We suggest a number of reasons for this in Chapter 2, though we cannot explore this in greater detail with the COVID case information we have. White non-Irish nationals are not overrepresented in the cases for which we have information. Non-Irish nationals as a whole are slightly overrepresented in terms of cases.

In terms of deaths, numbers are low in Ireland as the population is small. Ethnic minority groups that are identified are not overrepresented in deaths from COVID, in fact there were a very low number of deaths, if any, recorded for the White Traveller, Black/Black Irish and Asian/Asian Irish groups. This is not the pattern found in the US and the UK, but these are small population groups in Ireland, and we cannot rule out that this pattern will change over time. Non-Irish nationals 
as a whole are underrepresented in terms of deaths, relative to their share of the population, as with cases. As noted, the non-Irish and ethnic minority populations are much younger than White Irish/Irish nationals, on average, and deaths have been predominantly in the over 65 age category. We do not have detailed age information from the Computerised Infectious Disease Reporting database to investigate this further.

Chapter 4 focuses on the early labour market impact of the pandemic. Because of the extensive labour market supports introduced to cushion the impact of the pandemic on the incomes of those affected, the ILO unemployment definition the usual measure of labour market status - is not used as a measure of labour market impact. The chapter explores a number of different measures of the potential impact of the pandemic: receipt of COVID-related payments (from CSOcompiled statistics); fall in employment between Q1 2020 and Q2 2020; and those who record a COVID-related absence from work, even though they have, at least in principle, a job to go back to. As the latter two measures are drawn from the Irish Labour Force Survey, we can explore not only differences between national groups, but also to what extent these differences are related to the educational and demographic characteristics of non-Irish nationals, and the jobs in which they work, or were working in prior to the pandemic.

The pattern of labour market impact which emerges is not entirely consistent with the experience of other countries, in particular the United States, but also other European countries (OECD, 2020b). However, the findings do reflect some broader patterns of labour market integration previously observed in Ireland, in particular the disproportionate impact of the previous recession in Ireland on the employment of East European nationals (Barrett and Kelly, 2012).

Prior to the pandemic, EU-East nationals had high employment rates, higher than Irish nationals (McGinnity et al., 2020a) but were less likely to work in professionalmanagerial occupations (McGinnity et al., 2020b). In fact, as shown in Chapter 3, many worked in the manufacturing, retail and accommodation and food sectors. The accommodation and food sectors in particular have experienced substantial job losses, and EU-East nationals have been disproportionately negatively affected by the pandemic in terms of job loss and COVID-related absence. That said, neither the sectors they work in nor the fact that they typically work in jobs which cannot be done from home fully explain the disproportionate impact the pandemic has had on their labour market outcomes. This may reflect additional segregation of EU-East nationals within occupations and sectors that is not picked up in the broad categories included in our analyses, or it may be related to tenure (how long someone has been working in their job), firm size or their contract type (temporary or permanent, if they have one). It is consistent with Barrett and Kelly's (2012) 
finding that East European nationals in particular experienced a large fall in employment during the Great Recession in Ireland.

Early findings from Germany suggest it is non-EU nationals who have been disproportionately affected by the COVID pandemic (Anger et al., 2020). The finding for Ireland is more consistent with early research on the impact of the pandemic in Norway, where Central and East European immigrants have borne the brunt of the labour market impact (OECD, 2020b). Further analysis reveals that the fall in employment was particularly sharp for EU-East women in Ireland, as found in Norway (ibid.). Anger et al. (2020) also find migrant women disproportionately affected by job losses in the pandemic in Germany. While in general younger workers have been most affected by COVID job loss in Ireland overall, EU-East nationals aged 30 years and over have been harder hit than Irish nationals in the same age group in terms of employment decline.

EU-West nationals, as we know from previous work in Ireland, are very highly educated and have higher incomes than Irish nationals (McGinnity et al., 2020a). They are disproportionately found working in information/communication jobs, and the jobs they work in score high on remotability. In Chapter 4 we find that this group are not more likely to be in receipt of COVID-related payment, nor are they more likely to have experienced job loss than Irish nationals or, for the most part, be on temporary layoff due to COVID-19. ${ }^{60}$

Non-EU nationals are a diverse group in Ireland. They come from a range of different countries of origin and for different reasons (McGinnity et al., 2020b). Many come to work in Ireland under the employment permit scheme, typically in highly skilled jobs that are well paid and/or where the job is deemed to have a skill shortage (such as ICT professionals, engineering professionals). Others come to Ireland to study, not to work, though graduates are often entitled to work for a specified period after their study, and students are permitted to work restricted hours during term-time (see McGinnity et al., 2020a for details). Other non-EU nationals come to Ireland seeking international protection, or to be reunited with family members already settled in the State. Countries of origin are diverse; some of the top countries of origin of non-EU nationals resident in Ireland are the United States, India, Brazil, Nigeria, Pakistan and the Philippines (McGinnity et al., 2020b). Chapter 4 finds that this group have lower employment rates pre-pandemic, but are not disproportionately affected by job loss, compared to Irish nationals. They are somewhat more likely to be on COVID-related absence from work though not when the sectors they work in are accounted for. Their sectoral profile is diverse, 
like the group itself - from being disproportionately found in jobs in the health, and information/communication sectors, to also being overrepresented in accommodation and food (see Chapter 3).

Chapter 5 considers non-Irish nationals as key workers under Level 5 restrictions (October/November 2020). In other countries, migrants are disproportionately found to be essential workers - whether that is in healthcare, transport occupations or food production (e.g. Gelatt, 2020 in the US; also, OECD 2020b). This means they are contributing to the pandemic effort, but also - at least for front-line jobs - more vulnerable to the virus. Using a definition of essential services under Level 5 restrictions in Ireland, published in October 2020, we develop a measure of key workers using the data available. We find that overall, a smaller proportion of non-Irish workers (37 per cent) are classed as key workers compared to Irish employees (47 per cent). However, there is substantial variation within non-Irish groups: African and Asian nationals are much more likely to be key workers (42 per cent of workers in both groups are key workers). Other national groups, such as EU-West and non-EU 'Rest of the World' (mostly Latin American or non-EU East Europeans), are less likely to be key workers using this definition. Further analysis reveals around one-quarter of both Africans and Asians are key workers in healthcare or related occupations compared to 12 per cent of Irish workers. EU East-Europeans are more likely to be key workers in 'essential manufacturing' than Irish workers, and Irish workers are much more likely to be keyworkers in education than any of the non-Irish groups.

A clear limitation of this report is that, as with previous research on migrant integration in Ireland, we combine groups with different characteristics. In particular the labour market impact analysis does not allow us to distinguish different non-EU groups, though we know this group hides considerable variation. In addition, the survey and information used does not allow us to distinguish the impact of the COVID pandemic on asylum seekers and refugees, who have been found in other European countries to be a particularly vulnerable group (OECD, 2020b).

Finally, another obvious limitation of this analysis is that it is very early to assess the impact of the pandemic, as it is not at all clear how public health measures including business closures and other restrictions will evolve over the coming months and whether and if the patterns observed to date will remain consistent. This will be a task for future research when the data become available.

This report is early snapshot of the impact of the pandemic and how it varies by nationality. It is important that any potentially unequal impact of this crisis continues to be monitored to prevent vulnerable groups being adversely affected due to the impact of the pandemic. 


\section{References}

Adams-Prassl, A., T. Boneva, M. Golin and C. Rauh (2020). 'Inequality in the impact of the coronavirus shock: Evidence from real time surveys', IZA Discussion Paper No. 13183. Bonn: Institute of Labor Economics.

Anger, S., A. Bauer, M. Bossler, H. Brucker et al. (2020). Befunde der IAB-Forschung zur Corona-Krise - Zwischenbilanz une Ausblick, IAB, Nuremberg.

Baert, S., L. Lippens, E. Moens, P. Sterkens and J. Weytjens (2020). 'How Do We Think The COVID-19 Crisis Will Affect Our Careers (If Any Remain)?'. Discussion Paper Series No. 13164. IZA: Bonn. http://ftp.iza.org/dp13164.pdf [Accessed 17 August 2020].

Barrett, A. and E. Kelly (2012). 'The Impact of Ireland's Recession on the Labour Market Outcomes of its Immigrants', European Journal of Population, 28(1), pp. 99-111.

Barrett, A., F. McGinnity and E. Quinn (2017). Monitoring Report on Integration 2016. Dublin: ESRI/Dept. Justice and Equality.

Borjas, G.J. and H. Cassidy (2020). The Adverse Effect Of The Covid-19 Labour Market Shock On Immigrant Employment. Cambridge: National Bureau of Economic Research.

Capps, R., J. Batalova and J. Gelatt (2020). COVID-19 And Unemployment: Assessing The Early Fallout For Immigrants And Other U.S. Workers. Migration Policy Institute.

Central Statistics Office (CSO) (2020a). A Profile Of COVID-19 In Ireland - Using Census 2016 Household Data To Analyse COVID-19 Cases From March To November 2020. https://www.cso.ie/en/releasesandpublications/fp/fpac19/aprofileofcovid-19inirelandusingcensus2016householddatatoanalysecovid19casesfrommarchtonovember2020/ [Accessed 4 December 2020].

Central Statistics Office (CSO) (2020b). COVID-19 Deaths And Cases. Series 17. https://www.cso.ie/en/releasesandpublications/br/b-cdc/covid19deathsandcasesseries17/[Accessed 7 December 2020].

Central Statistics Office (CSO) (2020c). COVID-19 Deaths And Cases. Series 15. https://www.cso.ie/en/releasesandpublications/br/b-cdc/covid19deathsandcasesseries15/ [Accessed 20 November 2020].

Central Statistics Office (CSO) (2020d). Monthly Unemployment August 2020 - CSO https://www.cso.ie/en/releasesandpublications/er/mue/monthlyunempl oymentaugust2020/ [Accessed 21 September 2020].

Central Statistics Office (CSO) (2020e). Detailed COVID-19 Income Support And Live Register Tables. https://www.cso.ie/en/statistics/labourmarket/liveregister/detailedCovi d-19incomesupportandliveregistertables/ [Accessed 21 September 2020]. 
Citizensinformation.ie (2020a). COVID-19 Enhanced Illness Benefit. https://www.citizensinformation.ie/en/social_welfare/social_welfare_pa yments/disability_and_illness/covid19_enhanced_illness_benefit.html [Accessed 23 November 2020].

Citizensinformation.ie (2020b). COVID-19 Pandemic Unemployment Payment. https://www.citizensinformation.ie/en/social_welfare/social_welfare_pa yments/unemployed_people/covid19_pandemic_unemployment_payme nt.html\#la6b50 [Accessed 20 November 2020].

Citizensinformation.ie (2020c). Employment Wage Subsidy Scheme. https://www.citizensinformation.ie/en/employment/unemployment_an d_redundancy/employment_support_scheme.html\#_[Accessed 20 November 2020].

Darmody, M., E. Smyth and H. Russell (2020). Implications Of The Covid-19 Pandemic For Policy In Relation To Children And Young People: A Research Review. Dublin: Economic Social Research Institute. https://www.esri.ie/system/files/publications/SUSTAT94_3.pdf [Accessed 20 August 2020].

Department of Health (2020). Latest Updates On COVID-19 (Coronavirus). https://www.gov.ie/en/news/7e0924-latest-updates-on-Covid-19coronavirus/ [Accessed 14 October 2020].

Department of the Taoiseach (2020). Briefing On The Government's Response To

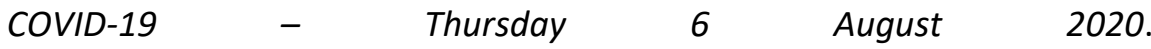
https://www.gov.ie/en/publication/75e06-briefing-on-the-governmentsresponse-to-Covid-19-thursday-6th-august-2020/ [Accessed 20 September 2020].

DES (2009). Developing The Workforce In The Early Childhood Care And Education Sector: Background Discussion Paper. Dublin: Department of Education and Science.

Donnelly, S. (2020). Letter From The Chief Medical Officer To The Minister For Health $4^{\text {th }}$ August. Department of Health.

ECDC (2020). COVID-19 Clusters And Outbreaks In Occupational Settings In The EU/EEA And The UK. Stockholm: European Centre for Disease Prevention and

Control. https://www.ecdc.europa.eu/sites/default/files/documents/COVID-19in-occupational-settings.pdf [Accessed 13 October 2020].

EMN (2020). New Migration And Asylum Measures Introduced In Response To COVID-19 The European Migration Network. https://emn.ie/newmigration-and-asylum-measures-introduced-in-response-to-covid-19/ [Accessed 13 November 2020].

EMN (2020a). Inform \# 3 - Maintaining Labour Migration In Essential Sectors In Times Of Pandemic. Inform \# 3 On the Impact of Covid-19 in the migration area. European Migration Network: Brussels.

EMN (2020b). EU and OECD Member States Responses to Managing Residence Permits and Migrant Unemployment during the Covid-19 Pandemic. Inform 
\# 1 On the Impact of Covid-19 in the migration area. European Migration Network: Brussels.

ENAR (2020). Impact of COVID-19 On Racialised Communities: Key Findings. https://www.enar-eu.org/IMG/pdf/key_findings_of_the_map.pdf [Accessed 17 August 2020].

Fahey, É., H. Russell, F. McGinnity and R. Grotti (2019). Diverse neighbourhoods: An analysis of the residential distribution of immigrants in Ireland, Dublin: ESRI/Department of Justice and Equality.

Fassani, F. and J. Mazza (2020). A Vulnerable Workforce: Migrant Workers In The COVID-19 Pandemic. Luxembourg: European Commission. https://publications.jrc.ec.europa.eu/repository/bitstream/JRC120730/a _vulnerable_workforce_migrant_workers_in_the_Covide19_pandemic_o nline.pdf [Accessed 5 August 2020].

Fernández-Reino, M. and R. McNeil (2020). Migrants' Labour Market Profile And The Health And Economic Impacts Of The COVID-19 Pandemic. Oxford: The Migration Observatory.

Fletcher, L. (2020). 'Concern over virus clusters at direct provision centres'. RTÉ, [online] https://www.rte.ie/news/ireland/2020/0802/1156959-directprovision/ [Accessed 4 August 2020].

FRA (2020a). Coronavirus Pandemic In The EU: Fundamental Rights Implications. Bulletin \#1. Luxembourg: Publications Office of the European Union. https://fra.europa.eu/sites/default/files/fra_uploads/fra-2020coronavirus-pandemic-eu-bulletin_en.pdf [Accessed 8 August 2020].

FRA (2020b). Country research - Roma and Travellers Survey 2019-Implications of COVID-19 pandemic on Roma and Travellers communities, Ireland Irish Centre for Human Rights, National University of Ireland Galway. Available at: https://fra.europa.eu/sites/default/files/fra_uploads/ie_report__covid-19_impact_on_roma_en.pdf

FRA (2020c). Roma And Travellers In Six Countries: Roma and Travellers Survey. Luxembourg: Publications Office of the European Union.

Gelatt, J. (2020). Immigrant Workers: Vital To The U.S. COVID-19 Response, Disproportionately Vulnerable. Migration Policy Institute.

Gov.ie (2020a). COVID-19 Pandemic Unemployment Payment. https://www.gov.ie/en/service/be74d3-Covid-19-pandemicunemployment-

payment/\#: :text=The\%20COVID\%2D19\%20Pandemic\%20Unemploymen t\%20Payment\%20is\%20available\%20to\%20employees,\%2D19\%20(Coron avirus)\%20pandemic.\&text=If\%20you\%20have\%20been\%20temporarily,f or\%20Short\%20Time\%20Work\%20Support. [Accessed 9 July 2020].

Gov.ie (2020b). Temporary COVID-19 Wage Subsidy Scheme. https://www.gov.ie/en/service/578596-Covid-19-wage-subsidy/ [Accessed 9 July 2020]. 
Gov.ie (2020c). Resilience And Recovery 2020-2021: Plan For Living With COVID-19. https://www.gov.ie/en/campaigns/resilience-recovery-2020-2021-planfor-living-with-Covid-19/ [Accessed 16 September 2020].

Gusciute, E. (2020). 'Leaving the most vulnerable behind: Reflection on the Covid19 pandemic and Direct Provision in Ireland', Irish Journal of Sociology, https://journals.sagepub.com/doi/full/10.1177/0791603520940145 [Accessed 5 August 2020].

Houses of the Oireachtas (2020). Special Committee On Covid-19 Response: Final Report. Dublin: Houses of the Oireachtas.

https://data.oireachtas.ie/ie/oireachtas/committee/dail/33/special_com mittee_on_covid_19_response/reports/2020/2020-10-09_final-reportof-the-special-committee-on-covid-19-response-sccr004_en.pdf [Accessed 16 November 2020].

HSE.ie (2020). Be On Call For Ireland - HSE.le. https://www.hse.ie/eng/services/news/newsfeatures/Covid19updates/oncall/ [Accessed 7 August 2020].

ILO (2020). COVID-19 And The World Of Work. Fifth Edition. International Labour Organization.

https://www.ilo.org/wcmsp5/groups/public/@dgreports/@dcomm/docu ments/briefingnote/wcms_749399.pdf [Accessed 1 August 2020].

IOM (2020). COVID-19 And Women Migrant Workers: Impacts and Implications. Geneva: International Organization for Migration.

IOM Ireland (2020). Rapid Policy Survey Report: The Irish Government's Policy Response To COVID-19 From A Migration Governance Lens. Dublin: International Organization for Migration.

Irish Centre for Human Rights, NUI Galway (2020). Implications of COVID-19 pandemic on Roma and Travellers communities.

Irish Refugee Council (2020). Powerless: Experiences Of Direct Provision During The Covid-19 Pandemic. Irish Refugee Council.

KNOMAD (2020). COVID-19 Crisis Through A Migration Lens: Migration and Development Brief 32. KNOMAD and World Bank Group.

Lan, F., C. Suharlim, S.N. Kales and J. Yang (2020). 'Association between SARS-CoV2 infection, exposure risk and mental health among a cohort of essential retail workers in the USA', Occupational and Environmental Medicine.

LaRochelle-Côté, S. and S. Uppa (2020). The Social And Economic Concerns Of Immigrants During The COVID-19 Pandemic. Statistics Canada. https://www150.statcan.gc.ca/n1/en/pub/45-280001/2020001/article/00012-eng.pdf?st=_ydigIrr [Accessed 20 August 2020].

Lucey, A. (2020). 'Locals take legal action to close direct provision centre in Cahersiveen', The Irish Times, https://www.irishtimes.com/news/crimeand-law/locals-take-legal-action-to-close-direct-provision-centre-incahersiveen-1.4252727 [Accessed 7 August 2020]. 
McGinnity, F., É. Fahey, E. Quinn, S. Arnold, B. Maître and P. O'Connell (2018a). Monitoring Report on Integration 2018. Dublin: ESRI / Department of Justice and Equality.

McGinnity, F., R. Grotti, S. Groarke and S. Coughlan (2018b). Ethnicity and nationality in the Irish labour market. Dublin: The Economic and Social Research Institute and Irish Human Rights and Equality Commission.

McGinnity, F., S. Enright, E. Quinn, B. Maître, I. Privalko, M. Darmody and M. Polakowski (2020a). Monitoring Report on Integration 2020, Dublin: The Economic and Social Research Institute and Department of Justice.

McGinnity, F., I. Privalko, É. Fahey, S. Enright and D. O'Brien (2020b). Origin and integration: a study of migrants in the 2016 Irish Census. Dublin: ESRI/ Department of Justice and Equality.

McQuinn, K., C. O'Toole, M. Allen-Coughlan and C. Coffey (2020). Quarterly Economic Commentary Summer 2020. Dublin: ESRI.

MRCI (2020). Working to the bone: the experiences of migrant workers in the meat sector in Ireland. Dublin: MRCI.

OECD (2020a). OECD Employment Outlook 2020: Worker Security And The COVID-19 Crisis. Paris: OECD Publishing.

OECD (2020b). 'Tackling Coronavirus (Covid-19): Contributing To A Global Effort', What is the impact of the COVID-19 pandemic on immigrants and their children? OECD Publishing.

Platt, L. and R. Warwick (2020). Are Some Ethnic Groups More Vulnerable To COVID-19 Than Others? Institute for Fiscal Studies.

Privalko, I., F. McGinnity and E. Quinn (2020). 'Non-Irish nationals working in meat processing in Ireland'. Unpublished note prepared for the National Outbreak Control Team (NOCT), June 2020.

Redmond, P. and S. McGuinness (2020a). Essential Employees During The Covid-19 Crisis. Dublin: Economic and Social Research Institute. https://doi.org/10.26504/sustat85.pdf.

Redmond, P. and S. McGuinness (2020b). Who Can Work from Home in Ireland? ESRI Survey and Statistical Report Series. Dublin: ESRI.

Timmons, S., M. Barjaková, D. Robertson, C. Belton and P. Lunn (2020). Public Understanding And Perceptions Of The Covid-19 Test-And-Trace System. Dublin: The Economic and Social Research Institute.

University of Bielefeld (2020). SARS-CoV-2 in Aufnahmeeinrichtungen und Gemeinschaftsunterkünften für Geflüchtete, Available at: https://pub.unibielefeld.de/download/2943665/2943668/FactSheet_PHNetworkCovid19_Aufnahmeeinrichtungen_v1_inkl_ANNEX.pdf [accessed on 25 September2020].

Walsh, B., P. Redmond and B. Roantree (2020). Differences In Severe Outcomes From Covid-19 Across Occupation In Ireland. Dublin: Economic Social Research Institute. https://www.esri.ie/system/files/publications/SUSTAT93.pdf. 
Watson, D., O. Kenny and F. McGinnity (2017). A Social Portrait of Travellers in Ireland. Dublin: ESRI.

White, C. and V. Nafilyan (2020). Coronavirus (COVID-19) Related Deaths By Ethnic Group, England And Wales: 2 March 2020 To 15 May 2020. Office for National Statistics.

WHO (2020). Weekly Epidemiological Update - 17 November 2020. https://www.who.int/publications/m/item/weekly-epidemiologicalupdate---17-november-2020 [Accessed 19 November 2020]. 


\section{Appendix}

\section{TABLE A1.1 OPERATIONAL DEFINITIONS AND EXAMPLES OF KEY WORKERS}

\begin{tabular}{|c|c|c|}
\hline $\begin{array}{c}\text { Type of } \\
\text { Essential Work }\end{array}$ & Operational Definition & Examples of Occupations \\
\hline $\begin{array}{l}\text { Health } \\
\text { Professionals }\end{array}$ & $\begin{array}{l}\text { NACE health sector } \\
\text { combined with ISCO } \\
\text { professionals category } \\
(2100-2635)\end{array}$ & $\begin{array}{l}\text { - } \text { Medical Doctors } \\
\text { - } \quad \text { Nursing and midwifery professionals } \\
\text { - } \quad \text { Paramedical practitioners } \\
\text { - } \quad \text { Pentists } \\
\text { - } \quad \text { Social work professionals }\end{array}$ \\
\hline $\begin{array}{l}\text { Health } \\
\text { Associate } \\
\text { Professionals }\end{array}$ & $\begin{array}{l}\text { NACE health sector } \\
\text { combined with ISCO } \\
\text { associate professionals } \\
\text { category (3100-3510) }\end{array}$ & 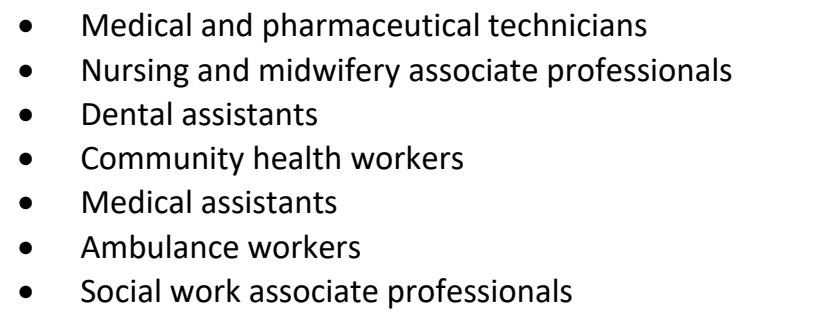 \\
\hline $\begin{array}{l}\text { Other Health } \\
\text { Employees }\end{array}$ & $\begin{array}{l}\text { NACE health sector } \\
\text { combined with ISCO } \\
\text { services and sales category } \\
(5100-5419)\end{array}$ & $\begin{array}{l}\text { - Healthcare assistants in hospitals, clinics and } \\
\text { - } \text { residential nursing care facilities } \\
\text { - } \quad \text { Hospital orderlies } \\
\text { - } \quad \text { Pharmacy aides } \\
\text { - } \quad \text { Medical imaging assistants }\end{array}$ \\
\hline Armed forces & $\begin{array}{l}\text { Public Administration and } \\
\text { Defence NACE sector } \\
\text { combined with ISCO } \\
\text { Armed Forces category }\end{array}$ & - All professions occupied by the armed defence forces \\
\hline $\begin{array}{l}\text { Defence and } \\
\text { Public } \\
\text { Administration }\end{array}$ & $\begin{array}{l}\text { Public Administration and } \\
\text { Defence NACE sector } \\
\text { combined with ISCO } \\
\text { Services and Sales } \\
\text { category (5400-5419) }\end{array}$ & $\begin{array}{ll}\text { - } & \text { An Garda Síochána } \\
\text { - } & \text { Prison guards } \\
\text { - } & \text { Firefighters }\end{array}$ \\
\hline Retail Sales & $\begin{array}{l}\text { Wholesale and Retail } \\
\text { Trade NACE sector } \\
\text { combined with the ISCO } \\
\text { Services and Sales } \\
\text { category (5200-5300) }\end{array}$ & $\begin{array}{ll}\text { - } & \text { Shop sales assistants } \\
\text { - } & \text { Shop keepers } \\
\text { - } & \text { Shop supervisors } \\
\text { - } & \text { Cashiers } \\
\text { - } & \text { Service station attendants } \\
\text { - } & \text { Food service counter attendant }\end{array}$ \\
\hline $\begin{array}{l}\text { Transport } \\
\text { Operatives }\end{array}$ & $\begin{array}{l}\text { Transport, Storage and } \\
\text { Communications NACE } \\
\text { sector combined with the } \\
\text { ISCO Plant and Machine } \\
\text { Operators category ( } 8300 \text { - } \\
8350 \text { ) }\end{array}$ & $\begin{array}{l}\text { - } \text { Bus drivers } \\
\text { - } \quad \text { Tram drivers } \\
\text { - } \text { Train drivers } \\
\text { - } \quad \text { Lorry drivers } \\
\text { - Taxi drivers }\end{array}$ \\
\hline Education & $\begin{array}{l}\text { Education NACE sector (all } \\
\text { workers) }\end{array}$ & $\begin{array}{ll}\text { - } & \text { Primary school teachers } \\
\text { - } & \text { Secondary school teachers } \\
\text { - } & \text { School administrators } \\
\text { - } & \text { School caretakers and cleaners }\end{array}$ \\
\hline
\end{tabular}

Contd. 
TABLE A1.1 CONTD.

\begin{tabular}{|c|c|c|}
\hline $\begin{array}{c}\text { Type of } \\
\text { Essential Work }\end{array}$ & Operational Definition & Examples of Occupations \\
\hline $\begin{array}{l}\text { Agricultural } \\
\text { employees }\end{array}$ & NACE sector (agriculture) & $\begin{array}{l}\text { - Employees in farming and fishing, including fruit and } \\
\text { vegetable harvesters }\end{array}$ \\
\hline $\begin{array}{l}\text { Utilities/waste } \\
\text { management }\end{array}$ & $\begin{array}{l}\text { NACE Sectors Utilities and } \\
\text { Waste Management }\end{array}$ & $\begin{array}{l}\text { - All employees who work in organisations providing } \\
\text { electric power, gas, piped water or those who manage } \\
\text { household and industrial waste }\end{array}$ \\
\hline $\begin{array}{l}\text { Manufacturing } \\
\text { (Essential only) }\end{array}$ & $\begin{array}{l}\text { NACE Manufacturing of } \\
\text { food, beverages, wood, } \\
\text { paper, chemicals, } \\
\text { pharmaceuticals, } \\
\text { computers and electronics } \\
\text { and electrical equipment }\end{array}$ & $\begin{array}{l}\text { All workers in these manufacturing subsectors: Skilled } \\
\text { workers, machine operators, production managers, } \\
\text { engineers and support staff in these organisations }\end{array}$ \\
\hline $\begin{array}{l}\text { Construction } \\
\text { employees }\end{array}$ & NACE Construction sector & - All construction employees \\
\hline
\end{tabular}


TABLE A4.1 FACTORS INFLUENCING EMPLOYMENT IN Q1 AND Q2 2020 (ODDS RATIOS)

\begin{tabular}{|c|c|c|c|c|}
\hline & 1 & 2 & 3 & 4 \\
\hline Female & 1 & 1 & 1 & 1 \\
\hline Male & $1.581 * * *$ & $1.746 * * *$ & $1.829 * * *$ & $1.731 * * *$ \\
\hline Ireland & 1 & 1 & 1 & 1 \\
\hline EU-West & 0.982 & $0.740 * *$ & $0.718 * *$ & $0.747^{*}$ \\
\hline EU-East & $0.673 * * *$ & $0.787^{*}$ & 0.907 & 0.991 \\
\hline Non-EU & $0.850 *$ & $0.583 * * *$ & $0.611^{* * *}$ & $0.690 * *$ \\
\hline Quarter 1 & 1 & 1 & 1 & 1 \\
\hline Q2 & $0.456 * * *$ & $0.443 * * *$ & $0.435^{* * *}$ & $0.421 * * *$ \\
\hline EU-West* \# qrtr=2 & & 1.123 & 1.119 & 1.121 \\
\hline EU-East \# qrtr=2 & & $0.632 * * *$ & $0.632 * * *$ & $0.614 * * *$ \\
\hline Non-EU \# qrtr=2 & & 1.125 & 1.104 & 1.093 \\
\hline Age & & $0.989 * * *$ & $0.986 * * *$ & $0.983 * * *$ \\
\hline Single & & 1 & 1 & 1 \\
\hline Married & & $1.112^{*}$ & 1.11 & 1.102 \\
\hline Separated/ Divorce & & 1.032 & 1.058 & 1.074 \\
\hline Couple no children & & 1 & 1 & 1 \\
\hline Couple with children & & 0.96 & 0.958 & 0.952 \\
\hline Lone parent & & $0.818 * *$ & $0.847^{*}$ & $0.854 *$ \\
\hline Living with parents & & $0.636 * * *$ & $0.664 * * *$ & $0.680 * * *$ \\
\hline Single/separated/Not applicable & & 0.91 & 0.915 & 0.907 \\
\hline Does not hold tertiary degree & & 1 & 1 & 1 \\
\hline Holds tertiary degree & & $2.013 * * *$ & $1.505^{* * *}$ & $1.468 * * *$ \\
\hline Low level remotability & & & 1 & \\
\hline Medium levels & & & $1.724 * * *$ & \\
\hline High levels & & & $1.983^{* * *}$ & \\
\hline Managers & & & & 1 \\
\hline Professionals & & & & 0.932 \\
\hline Technicians & & & & $0.861^{*}$ \\
\hline Clerical support & & & & 0.873 \\
\hline Services and sales & & & & $0.550 * * *$ \\
\hline Skilled agricultural & & & & 1.304 \\
\hline Craft and related & & & & $0.535 * * *$ \\
\hline Plant and machinery & & & & $0.529 * * *$ \\
\hline Elementary occupations & & & & $0.533 * * *$ \\
\hline Sector ref: C Manufacturing & & & & 1 \\
\hline A-B Agri mining and quarrying & & & & $1.669 * * *$ \\
\hline D-E Utilities & & & & 1.035 \\
\hline F Construction & & & & $0.494 * * *$ \\
\hline G-H Retail, wholesale, transport & & & & $0.740 * * *$ \\
\hline I Accommodation \& food & & & & $0.279 * * *$ \\
\hline J-K-L Information \& financial services & & & & 0.936 \\
\hline M-N Professional scientific tech \& admin & & & & $0.696 * * *$ \\
\hline O-P-Q Public admin, education, health & & & & $0.751 * * *$ \\
\hline Observations & 27,895 & 27,895 & 27,895 & 27,895 \\
\hline Pseudo R-squared & 0.034 & 0.06 & 0.071 & 0.091 \\
\hline chi2 & $1,091.5$ & 1,894 & 2,259.9 & 2,882 \\
\hline Log Likelihood & $-15,341.9$ & $-14,940.7$ & $-14,757.7$ & $-14,446.7$ \\
\hline
\end{tabular}

Source: $\quad$ LFS 2020 Q1 and Q2.

Note: $\quad$ Restricted to those aged 15-64 years and valid on all covariates. For those out of work previous occupation/sector is used. Those who have no previous occupation are excluded. Models are unweighted. An odds ratio of greater than 1 means the group are more likely to be employed compared to the reference category. An odds ratio less than 1 means the group is less likely to be on COVID-related absence. ${ }^{* * *} p<0.001 ;{ }^{* *} p<0.01 ;{ }^{*} p<0.05$. 
TABLE A4.2 FACTORS INFLUENCING EMPLOYMENT IN Q1 AND Q2 2020 FOR MEN AND WOMEN (ODDS RATIOS)

\begin{tabular}{|c|c|c|c|c|}
\hline & $\begin{array}{c}(1) \\
\text { Men }\end{array}$ & $\begin{array}{c}(2) \\
\text { Men } \\
+ \text { Controls } \\
\end{array}$ & $\begin{array}{c}\text { (3) } \\
\text { Women }\end{array}$ & $\begin{array}{c}\text { (4) } \\
\text { Women } \\
+ \text { Controls }\end{array}$ \\
\hline Ireland & 1 & 1 & 1 & 1 \\
\hline EU-West & 0.87 & 0.712 & 0.978 & 0.802 \\
\hline EU-East & 0.816 & 0.859 & 0.845 & 1.137 \\
\hline Non-EU & 0.964 & 0.715 & $0.716^{*}$ & $0.684 *$ \\
\hline$q r t r=1$ & 1 & 1 & 1 & 1 \\
\hline qrtr $=2$ & $0.419 * * *$ & $0.373 * * *$ & $0.503 * * *$ & $0.460 * * *$ \\
\hline EU-West \# qrtr=1 & 1 & 1 & 1 & 1 \\
\hline EU-West \# qrtr=2 & 1.263 & 1.207 & 0.985 & 1.026 \\
\hline EU-East \# qrtr=1 & 1 & 1 & 1 & 1 \\
\hline EU-East \# qrtr=2 & 0.764 & 0.701 & $0.561 * *$ & $0.524^{* * *}$ \\
\hline Non-EU \# qrtr=1 & 1 & 1 & 1 & 1 \\
\hline Non-EU \# qrtr=2 & 1.156 & 1.228 & 0.979 & 0.968 \\
\hline Controls for age, education & No & Yes & No & Yes \\
\hline Controls for family characteristics & No & Yes & No & Yes \\
\hline Controls for occupation and sector & No & Yes & No & Yes \\
\hline Observations & 14,336 & 14,336 & 13,559 & 13,559 \\
\hline Pseudo R-squared & 0.031 & 0.121 & 0.024 & 0.069 \\
\hline chi2 & 456.1 & $1,802.8$ & 398.6 & $1,151.8$ \\
\hline II & $-7,240.1$ & $-6,566.8$ & $-8,087.9$ & $-7,711.3$ \\
\hline
\end{tabular}

Source: LFS 2020 Q1 and Q2.

Note: $\quad * p<0.05 * * p<0.01 * * * p<.001$ 
TABLE A4.3 FACTORS INFLUENCING EMPLOYMENT IN Q1 AND Q2 2020 FOR YOUNGER AND OLDER WORKERS (ODDS RATIOS)

\begin{tabular}{|c|c|c|c|c|}
\hline & (1) & (2) & (3) & (4) \\
\hline & $<30$ years & $\begin{array}{c}<30 \text { years } \\
\text { (+ controls) }\end{array}$ & $30+$ years & $\begin{array}{c}30+\text { years } \\
\text { (+ controls) }\end{array}$ \\
\hline Ireland & 1 & 1 & 1 & 1 \\
\hline EU-West* & 0.842 & 0.530 & 0.936 & 0.793 \\
\hline EU-East & 0.843 & 1.110 & 0.829 & 0.991 \\
\hline Non-EU & 1.300 & 1.047 & $0.722 *$ & $0.617 * * *$ \\
\hline$q r t r=1$ & 1 & 1 & 1 & 1 \\
\hline qrtr $=2$ & $0.315 * * *$ & $0.251 * * *$ & $0.501 * * *$ & $0.468 * * *$ \\
\hline EU-West* \# qrtr=1 & 1 & 1 & 1 & 1 \\
\hline EU-West* \# qrtr=2 & 1.429 & 1.340 & 1.034 & 1.041 \\
\hline EU-East \# qrtr=1 & 1 & 1 & 1 & 1 \\
\hline EU-East \# qrtr=2 & 0.617 & 0.726 & $0.638 * *$ & $0.589 * * *$ \\
\hline Non-EU \# qrtr=1 & 1 & 1 & 1 & 1 \\
\hline Non-EU \# qrtr=2 & 0.946 & 0.794 & 1.134 & 1.154 \\
\hline Female & 1 & 1 & 1 & 1 \\
\hline Male & $1.253^{* * *}$ & 1.113 & $1.671 * * *$ & $1.923 * * *$ \\
\hline $\begin{array}{l}\text { Controls for education and family } \\
\text { characteristics }\end{array}$ & No & Yes & No & Yes \\
\hline Controls for occupation and sector & No & Yes & No & Yes \\
\hline Observations & 4,936 & 4,936 & 22,959 & 22,959 \\
\hline Pseudo R-squared & 0.059 & 0.151 & 0.032 & 0.084 \\
\hline chi2 & 353.4 & 904.1 & 837.1 & $2,174.1$ \\
\hline II & $-2,809.4$ & $-2,534.0$ & $-12,462.6$ & $-11,794.1$ \\
\hline
\end{tabular}

Source: LFS 2020 Q1 and Q2.

Note: $\quad * p<0.05 * * p<0.01 * * * p<.001$. 
TABLE A4.4 FACTORS ASSOCIATED WITH UNEMPLOYMENT OR INACTIVITY DUE TO NON-COVID REASONS (COMPARED TO EMPLOYMENT) Q2 2020; RELATIVE RISK RATIOS

\begin{tabular}{|c|c|c|c|c|}
\hline Unemployed_or_inactive_for_other & & & & \\
\hline Ireland & 1 & 1 & 1 & 1 \\
\hline EU-West* & 1.251 & $1.669 * * *$ & $1.724 * * *$ & $1.578 * *$ \\
\hline EU-East & $1.815^{* * *}$ & $2.151 * * *$ & $1.852 * * *$ & $1.646 * * *$ \\
\hline Non-EU & $1.467^{*}$ & $2.267 * * *$ & $2.203^{* * *}$ & $1.857 * * *$ \\
\hline Female & 1 & 1 & 1 & 1 \\
\hline Male & $0.588 * * *$ & $0.528 * * *$ & $0.506 * * *$ & $0.535^{* * *}$ \\
\hline age & $1.019 * * *$ & $1.036 * * *$ & $1.039 * * *$ & $1.044 * * *$ \\
\hline Single & & 1 & 1 & 1 \\
\hline Married & & $0.686 * * *$ & $0.692 * * *$ & $0.695^{* *}$ \\
\hline Separated/ Divorced & & 0.906 & 0.894 & 0.891 \\
\hline Couple no children & & 1 & 1 & 1 \\
\hline Couple with children & & 0.896 & 0.903 & 0.920 \\
\hline Lone parent & & 1.189 & 1.161 & 1.168 \\
\hline Child of couple or child of lone parent & & $2.059 * * *$ & $2.008 * * *$ & $2.013^{* * *}$ \\
\hline Single/separated/Not applicable & & 1.033 & 1.031 & 1.047 \\
\hline Does not hold tertiary degree & & 1 & 1 & 1 \\
\hline Holds tertiary degree & & $0.419 * * *$ & $0.562 * * *$ & $0.569 * * *$ \\
\hline Low levels & & & 1 & \\
\hline Medium levels & & & $0.596 * * *$ & \\
\hline High levels & & & $0.482 * * *$ & \\
\hline Managers & & & & 1 \\
\hline Professionals & & & & 1.145 \\
\hline Technicians & & & & 1.194 \\
\hline Clerical support & & & & 1.304 \\
\hline Services and sales & & & & $2.187 * * *$ \\
\hline Skilled agricultural & & & & $0.477^{*}$ \\
\hline Craft and related & & & & $1.708 * *$ \\
\hline Plant and machinery & & & & $1.678 * *$ \\
\hline Elementary occ & & & & $2.143^{* * *}$ \\
\hline A-B Agri mining and quarrying & & & & 0.667 \\
\hline C Manufacturing & & & & 1 \\
\hline D-E Utilities & & & & 1.105 \\
\hline F Construction & & & & 1.190 \\
\hline G-H Wholesale retail transportation & & & & 1.019 \\
\hline I Accommodation and food & & & & $4.121 * * *$ \\
\hline J-K-L Information financial services and real estate & & & & 1.078 \\
\hline M-N Professional scientific technical and admin & & & & 1.000 \\
\hline O-P-Q Public admin education health and social work & & & & 0.795 \\
\hline Observations & 12,735 & 12,735 & 12,735 & 12,735 \\
\hline Pseudo R-squared & 0.011 & 0.055 & 0.072 & 0.124 \\
\hline chi2 & 236.6 & $1,128.8$ & $1,486.2$ & $2,556.8$ \\
\hline Log Likelihood & $-10,210.1$ & $-9,764.0$ & $-9,585.3$ & $-9,050.1$ \\
\hline
\end{tabular}

Source: LFS 2020 Q2. * $p<0.05 * * p<0.01 * * * p<.001$

Note: Restricted to those aged 15-64 years and valid on all covariates. Models are unweighted. A relative risk ratio of greater than 1 means the group are more likely to be on Unemployed/Inactive for another reason rather than Employed compared to the reference category. An RRR less than 1 means the group is less likely to Unemployed/Inactive for another reason rather than Employed compared to the reference category. 
TABLE A4.5 FACTORS ASSOCIATED WITH COVID ABSENCE, UNEMPLOYMENT OR INACTIVITY DUE TO NON-COVID REASONS (COMPARED TO EMPLOYMENT) WITH INTERACTIONS

\begin{tabular}{|c|c|c|c|}
\hline & (1) & (2) & (3) \\
\hline & EU*Education & EU*Age & EU*Gender \\
\hline Controls for family characteristics & Yes & Yes & Yes \\
\hline Controls for occupation \& sector & Yes & Yes & Yes \\
\hline \multicolumn{4}{|l|}{ COVID Absence } \\
\hline Ireland & 1 & 1 & 1 \\
\hline EU-West* & 1.417 & 1.571 & 1.372 \\
\hline EU-East & 0.981 & 1.074 & $1.448^{*}$ \\
\hline Non-EU & 0.973 & 1.668 & 1.253 \\
\hline Female & 1 & 1 & 1 \\
\hline Male & $0.703^{* * *}$ & $0.700 * * *$ & $0.717^{* * *}$ \\
\hline Under 30 & 1 & 1 & 1 \\
\hline 30 and Over & 0.963 & 0.993 & 0.978 \\
\hline No tertiary degree & 1 & 1 & 1 \\
\hline Tertiary degree & $0.578 * * *$ & $0.601 * * *$ & $0.601 * * *$ \\
\hline EU-West* \# Holds tertiary degree & 0.822 & & \\
\hline EU-East \# Holds tertiary degree & $2.113^{* *}$ & & \\
\hline Non-EU \# Holds tertiary degree & 1.107 & & \\
\hline EU-West* \# 30 and Over & & 0.767 & \\
\hline EU-East \# 30 and Over & & 1.303 & \\
\hline Non-EU \# 30 and Over & & 0.561 & \\
\hline EU-West* \# Male & & & 0.807 \\
\hline EU-East \#Male & & & 0.861 \\
\hline Non-EU \#Male & & & 0.694 \\
\hline \multicolumn{4}{|c|}{ Unemployed or inactive for other reason } \\
\hline Ireland & 1 & 1 & 1 \\
\hline EU-West* & 1.583 & 1.276 & 1.317 \\
\hline EU-East & 1.043 & $2.129 *$ & 1.368 \\
\hline Non-EU & 1.067 & 0.611 & $1.760 *$ \\
\hline Female & 1 & 1 & 1 \\
\hline Male & $0.550 * * *$ & $0.548 * * *$ & $0.565^{* * *}$ \\
\hline Under 30 & 1 & 1 & 1 \\
\hline 30 and Over & 1.089 & 1.114 & 1.096 \\
\hline Does not hold tertiary degree & 1 & 1 & 1 \\
\hline Holds tertiary degree & $0.505^{* * *}$ & $0.517 * * *$ & $0.511 * * *$ \\
\hline EU-West* \# Holds tertiary degree & 0.862 & & \\
\hline EU-East \# Holds tertiary degree & 1.449 & & \\
\hline Non-EU \# Holds tertiary degree & 1.264 & & \\
\hline EU-West \# 30 and Over & & 1.137 & \\
\hline EU-East \# 30 and Over & & 0.510 & \\
\hline Non-EU \# 30 and Over & & 2.206 & \\
\hline
\end{tabular}


TABLE A4.5 CONTD.

\begin{tabular}{|c|c|c|c|c|}
\hline & (1) & (2) & (3) \\
\hline & & EU*Education & EU*Age & EU*Gender \\
\hline \multicolumn{3}{|c|}{ EU-West* \# Male } & & 1.222 \\
\hline \multicolumn{2}{|c|}{ EU-East \#Male } & & & 0.783 \\
\hline \multicolumn{2}{|c|}{ Non-EU \#Male } & & & $0.429 *$ \\
\hline \multicolumn{2}{|c|}{ Observations } & 12,735 & 12,735 & 12,735 \\
\hline \multicolumn{2}{|c|}{ Pseudo R-squared } & 0.117 & 0.117 & 0.117 \\
\hline \multicolumn{2}{|l|}{ II } & $-9,121.7$ & $-9,121.7$ & $-9,123.6$ \\
\hline \multicolumn{2}{|l|}{ chi2 } & $2,413.5$ & $2,413.6$ & $2,409.7$ \\
\hline \multicolumn{5}{|c|}{$\begin{array}{ll}\text { Source: } & \text { LFS } 2020 \text { Q2. } \\
\text { Note: } & \text { Restricted to those aged } 15-64 \text { years and valid on all covariates. Models are unweighted. Multinomial model. A relative risk ratio of }\end{array}$} \\
\hline \multicolumn{5}{|c|}{$\begin{array}{l}\text { Note: Restricted to those aged } 15-64 \text { years and valid on all covariates. Models are unweighted. Multinomial model. A relative risk ratio of } \\
\text { greater than } 1 \text { means the group are more likely to be on COVID-related absence rather than employed compared to the reference } \\
\text { category. An RRR less than } 1 \text { means the group is less likely to be absent compared to the reference group. The second half of the table } \\
\text { shows the RRRs for unemployment/inactive for a non-COVID reason. }{ }^{*} p<0.05^{* *} p<0.01{ }^{* *} p<.001 .\end{array}$} \\
\hline
\end{tabular}


Whitaker Square,

Sir John Rogerson's Quay, Dublin 2

Telephone +35318632000

Email admindesri.ie

Web www.esri.ie

Twitter RESRIDublin 